\title{
Foreign multinational enterprises in the food and beverages industries of the BRICS.
}

\author{
Ruth Rama \\ Institute of Economics, Geography and Demography (IEGD) \\ CSIC - Consejo Superior de Investigaciones Científicas \\ (National Research Council of Spain) \\ C/ Albasanz, 26-28; 28037 Madrid, Spain \\ ruth.rama@cchs.csic.es
}

\begin{abstract}
:
The bulk of food industry FDI to the BRICS seems to have gone to China and Brazil. FDI has contributed to industrial structural change and to changes in consumption patterns in the host countries. It has mainly focused on high value added subsectors and in concentrated markets. In spite of this, rivalry between foreign investors and the emergence of strong domestic firms has introduced some competition. Contribution to capital creation seems limited since Greenfield investment, as a mode of entry, has been far less popular than mergers and acquisitions; moreover, it has been centered almost exclusively in China and Russia. The chapter also studies the embeddedness of food and beverages MNEs in the BRICS. The longer business history of these firms and their substantial, continuous presence in Brazil suggest that those companies may have developed more interactions with domestic companies there than in the rest of the BRICS. However, business partnerships have been more important in China, India and Russia. Acquisitions have been more important in Brazil and South Africa. The companies are performing now R\&D in the BRICS, notably in India and Brazil. Quality R\&D seems to be mainly performed in India and China.
\end{abstract}

Key words: multinational enterprises, food and beverages industry, internationalisation of R\&D, Brazil, Russia, India, China, South Africa, development.

JEL Codes: F23, O14, O19.

Paper prepared for the UNIDO project: The Untold Story: Structural Change for Poverty Reduction: The Case of the BRICS 


\section{Introduction}

This chapter analyses Foreign Direct Investment (FDI) in the food and beverages processing industry of the BRICS, a crucial industry for a variety of reasons. In terms of value added, it is the most important industry of Russia and South Africa; the second of Brazil and the fourth of India and China (See Naudé et al Chapter). The food and beverages processing industry (hereafter, F\&B industry) also plays a substantial role regarding the manufacturing employment of these countries. Updated technology and expertise are necessary requirements for their F\&B industries given their large populations and accelerated processes of urbanisation. Such processes are contributing to changes in diet, with a transition from staple foods and grains, to more processed foods. In addition, the mastering of new technologies may help these countries to increase their exports of processed food (Athukorala \& Sen, 1998), an important consideration since some of these nations are exporters of commodities, and processed foods and drinks ${ }^{1}$. Finally, as noted by some authors, the modern food and beverages industry cannot be seen as a backward and traditional sector (Christensen et al., 1996). This industry is certainly not a high-tech industry; nevertheless, they claim, it is at the forefront of industries in the application of a breath of different scientific advances. Given its large size, it possesses a high potential for becoming a "carrier industry" for embodying technology advances developed in upstream industries. Therefore, the development of the F\&B industry may stimulate, in turn, the development of other manufacturing industries and technical services in the BRICS.

This chapter reviews the literature and supplies empirical evidence to assess whether FDI may contribute to development of the F\&B industries of the BRICS. Many developing countries expect that MNEs will contribute to providing skills and

\footnotetext{
${ }^{1}$ According to the FAO, in 2009, Brazil was one of the 20 top exporters of agricultural commodities. FAO. http://faostat3.fao.org. July 2012. According to UNCTAD (2009), in 20022006, Brazil was among the top10 exporters of green coffee $\left(1^{\text {st }}\right)$, oilseeds $\left(1^{\text {st }}\right)$, soya beans $\left(2^{\text {nd }}\right)$ and corn. In the same period, China was among the top 10 exporters of tea $\left(2^{\text {nd }}\right)$, rice $\left(2^{\text {nd }}\right)$, corn, oilseeds, roots and tubers, and soya beans. India was among the top 10 exporters of oilseeds, tea, and rice; the Russian Federation was among the top 10 exporters of wheat, and South Africa was among those of corn. Food, beverages and tobacco account for $30.5 \%$ of Brazilian manufacturing exports (See Naudé et al Chapter).
} 
technology that will ultimately enhance the competitiveness of domestic firms. However, these expectations are not always fulfilled (see, for instance, UNCTAD, 2001).

Most Foreign Direct Investment (hereafter, FDI) is still a North-North phenomenon. As will be seen below, FDI in food and beverages goes primarily to industrialised countries, whose importance appears to have increased in recent years, despite the flows received by developing countries also having grown. In addition to common factors which may limit the possibilities of certain developing countries to attract FDI to any industrial sector (see, for instance, Flores \& Aguilera, 2007), other factors may also limit these countries' possibilities to attract FDI specifically to their F\&B industry. For instance, food consumption is still largely culturally bound. Differences in local tastes are significant and persistent all over the world. Consequently, world leaders in the F\&B industry are more likely to expand their operations to countries that display cultural characteristics similar to those of the home-countries, most of them Western countries ( $F$ Filippaios \& Rama, 2011).

Therefore, our first step will be to study trends of inward FDI in the food and beverages industries of the BRICS and identify attractors which may have encouraged the inflow of capital. Also, I will briefly comment some research results regarding the possible effects of food industry FDI on industry structure, competition and food consumption patterns of the host countries.

The second step will consist of the analysis of the potential contribution of FDI to the F\&B industries of the BRICS via the transmission of managerial capabilities and spillovers of knowledge. In doing so, the paper analyses whether food and beverages MNEs are embedded in the F\&B industries of the BRICS. As MNEs operating in other sectors, food and beverage MNEs may have few linkages with the local economy. While joint-ventures (hereafter JV) seem to offer more potential for collaboration between MNEs and local actors, acquisitions are less likely to promote linkages with local partners. Greenfield investment, in turn, contributes to the creation of capital. Therefore, to analyse modes of entry of MNEs in the food and beverages industries of BRICS is relevant to understand whether FDI may contribute to the development of these industries.

The chapter also analyses whether major food and beverages MNEs perform R\&D locally. These firms often prefer to locate their R\&D investments 
either in the home country or in the world centres of excellence for this industry, located in a few countries of Northern Europe and, especially, in the US (Cantwell \& Janne, 2000; Christensen et al., 1996). These location strategies may limit the access of the BRICS to state-of-the arts technology since major MNEs are very important actors in this technological field. The world's 100 largest food and beverages MNES (hereafter, the Top 100) supply approximately $50 \%$ of the patentable inventions usable in the F\&B industry, and in auxiliary industries worldwide (O. Alfranca et al., 2002; P. Patel \& Pavitt, 1991). These companies generate patented innovation in food but also in drugs (for instance, veterinarian medicine), biotechnology and chemistry used in agro-food production (O Alfranca et al., 2004). However, transmission of knowledge and technical and scientific collaboration depend to a high degree on geographic proximity (Feldman \& Audretsch, 1996). The importance of physical proximity, for instance between the user and the producer of technology, is corroborated by the historical co-evolution of successful agro-food sectors and auxiliary industries in some countries now highly developed (Andersen \& Lundvall, 1988). Consequently, it is essential to understand better whether major F\&B multinationals locate these important activities in the BRICS.

Section 2 analyses changes in the structure the food industry of the BRICS. Section 3 describes the sources of information used in this chapter and analyses global trends of food and beverages industry FDI worldwide. Section 4 studies trends of food and beverages industry FDI in the BRICS, compares these countries and review studies dealing with the possible effects of MNEs on competition and industrial concentration in these industries. Section 5 discusses the embeddedness of food and beverage MNEs in the BRICS from three points of view: i) acquaintance of the companies with the host country, ii) local business partnerships and iii) performance of local R\&D. Section 6 provides conclusions.

\section{Structural change in the food and beverages industry}

The F\&B of the BRICS have witnessed some structural change, as measured by changes in the value added $(\mathrm{VA})^{2}$ of different subsectors. With the exception of Russia, where almost all sub sectors shrunken, the share of the

\footnotetext{
${ }^{2}$ www.unido.org. June 2012.
} 
processed meat, fish, vegetables and fats subsector increased in all countries (Table 1). Changes towards high value added segments of these industries may be related to changes in food consumption patterns Certain authors argue that a new middle class oriented towards a Western lifestyle and diet is rising in this group of countries (see, for instance, Heyder \& Theuvsen, 2011). In a similar vein, others claim that in emerging economies, urban dwellers now tend to follow international patterns of food consumption (Ayadi et al., 2006; Tozanli, 2005). This new diet allegedly includes less grains and staples ${ }^{3}$, and more animal protein, sugar and convenience food.

New consumption patterns of at least part of population may have attracted food and beverage MNEs to the BRICS. These companies sell a product mix all over the world highly determined by the diet of industrialised countries, in general, highly caloric foodstuffs and animal protein (Grebe \& Kñakal, 1987; Rama, 1985). By the end of the 1990s, beverages and tobacco, and "other food products" (i.e. high value added foodstuffs) were the two most important items in the total sales of US affiliates in food and kindred products operating in foreign countries (Pick \& Worth, 2005).

Except in India, where consumption of animal products has been traditionally low for religious and cultural reasons, meat, poultry and dairy products are some of the main agricultural products targeted by foreign investors ${ }^{4}$ in the BRICS. These products were mainly the following up to 2009 (UNCTAD, 2009):

Brazil: Meat and poultry, sugar cane, fruits

Russia: Dairy products, wheat and other grains.

India: Wheat and grains, rice.

China: Meat and poultry, vegetables

Moreover, in the BRICS, MNEs tend to invest in high valued-added segments of the F\&B processing industry such as confectionary; pre prepared foods, alcoholic beverages, etc. (I come back to this question below).

\footnotetext{
${ }^{3}$ Note, however, that the share of grain milling increased in India and China, which are less likely to follow the typical Western diet for religious or cultural reasons (see, for instance, Shono et al., 2000).

${ }^{4}$ Includes both food processing MNEs and agricultural MNEs. No data for South Africa provided.
} 
Though certain authors assume that the expansion of food and beverage MNEs has been a quasi-automatic response to changes in the diet, interactions between these companies and their host-countries have, in fact, been bidirectional. The expansion of products marketed by these firms began to displace, to some extent, traditional substitute products as early as the 1970s in some developing countries (CTC, 1981). Some authors have argued that these changes have been, in part, induced by the advertisement and marketing campaigns led by the companies (Arroyo et al., 1985; Belik, 1994; CTC, 1981). The strategies of food MNEs such as Kellogg (US) and Unilever (Dutch-British) in Asian countries, India included, that did not eat bread (and, hence, margarine) or breakfast cereals seem to support this point of view (Cuervo-Cazurra et al., 2007; Jones, 2005).

FDI is contributing to structural change in the food and beverages industries of the BRICS, given its strong presence in high value-added sub sectors. However, to evaluate the benefits accruing to the host-economies, effects of this shift on local agriculture and the balance of payment should be evaluated. A study of US outward food industry FDI in 23 countries during the 1990s suggests that MNEs stimulated local agriculture when the host country was already competitive in agricultural production; in other cases, however, these companies stimulated instead massive imports of raw materials (Barkley, 2005).

\section{Table 1}

\section{Global trends of FDI in the food and beverages industry}

\subsection{Data}

At sector level, data regarding FDI and MNE activity are frequently patchy. This problem has often restricted attempts to map MNE activity by sector; therefore, I combine several data sources. I employ data on FDI investment ${ }^{5}$ flows and stock provided by the Survey of Current Business, EUROSTAT and Japan's Ministry of Finance for major source countries (regions) of capital in the

\footnotetext{
${ }^{5}$ Flow data record the value of investments undertaken in a specific year, while stock data represent the net accumulated value resulting, at a point in time, from past flows (letto-Gillies, 2005)
} 
international F\&B industry, namely the US, the European Union and Japan. However, as no comprehensive international statistics are available at the sectoral/country level, this information needs to be complemented by other sources. Thus, I use an upstream measure, i.e. data concerning the location of the affiliates ${ }^{6}$ of the world's 100 largest food and beverage MNEs provided by the AGRODATA database ${ }^{7}$.

The distribution of affiliates is one of the proxies proposed by the OECD (2004) to construct MNE-related globalisation indicators. While a minor rebalancing of a company's sales portfolio or mere currency appreciation/depreciation may erroneously suggest substantial changes in its geographic patterns (Osegowitsch \& Sammartino, 2008), the analysis of affiliate location provides a measurement less subject to short-term changes.

\subsection{Evolution of flows and stocks}

The F\&B industry is considered to be a non-cyclical sector, a "refuge" industry in times of crisis, attracting institutional investors (e.g. pension funds), especially in the USA and, to a lesser extent, in Europe. The new configuration of shareholders has apparently been accompanied by demands for relentless rhythms of growth and the achievement of global goals by F\&B companies, which have often contributed to promoting their worldwide expansion (Caswell, 1987; Muller \& Van Tulder, 2005; Palpacuer \& Tozanli, 2008). Between 1989-1991 and 2005-2007, outward $\mathrm{FDI}^{8}$ flows quadrupled in food, beverage and tobacco manufacturing, due to a range of new circumstances and policy measures, such as the liberalisation of capital and trade, the formation or enlargement of trading blocs (e.g. the EU), the adoption of the market system in erstwhile state-managed economies and increasing per capita gross domestic product (GDP) in the

\footnotetext{
${ }^{6}$ An affiliate is an incorporated or unincorporated enterprise in which an investor owns a stake that permits a degree of control of the management of that enterprise ((letto-Gillies, 2005))

${ }^{7}$ The sources of AGRODATA, a database compiled by the Institut Agronomique Méditérrannéen de Montpellier (France), are Moody's industrial Manual, the Fortune Directory of the 500 larges corporations, the "Dossier 5.000" of the largest European corporations, Dun \& Bradstreet, the annual reports of the enterprises, etc.

${ }^{8}$ According to UNCTAD, "FDI refers to an investment made to acquire lasting interest in enterprises operating outside of the economy of the investor. Further, in cases of FDI, the investor's purpose is to gain an effective voice in the management of the enterprise. The most important characteristic of FDI, which distinguishes it from foreign portfolio investment, is that it is undertaken with the intention of exercising control over an enterprise". http://www.unctad.org/
} 
emerging economies. Most FDI originates in developed countries and this industry is no exception. The share of developed countries in outward FDI flows channelled to the world's food, beverage and tobacco industry fell between 19891991 and 2005-2007, though the reduction in their share was moderate (from $98 \%$ to $95 \%$ of total). However, the composition of outward FDI in this sector changed substantially between the two periods. As Tozanli $(2005$, p.22) states, the world ranking of the Top 100 "shows the supremacy of the Triad, even though the composition within the Triad has changed". During 1978-2000, according to her study, $88 \%$ of these top companies were $\operatorname{Triad-based}^{9}$, and this figure remained stable throughout. As she notes, however, changes within the Triad are apparent, and especially the emergence of very large Japanese companies since the 1970s.

The outward food and beverages FDI flows of developing economies multiplied by ten from 1989-1991 to 2005-2007 (UNCTAD, 2009). Their share increased from $2.0 \%$ to $5.4 \%$ during this period. However, their share of agricultural outward FDI increased much more dynamically, from $8.8 \%$ to $43.3 \%$ of total. At the same time, the share of developed countries decreased quickly. Part of the agricultural outward FDI of developing countries, consists of investments made by BRICS based food and beverages processors that control various segments of the food value chain (Nazareth Satyanand, 2011; Pozzobon, 2008). These native MNES sometimes own land in other developing countries, and processing and retailing facilities in developed countries. This is a relatively new phenomenon. Up to now most of the literature focused on global food chains controlled by companies based in developed countries (see Nixson's chapter).

All over the world, the F\&B industry is dominated by small and mediumsized enterprises (SMEs), although the Top 100 accounted for approximately $27 \%$ of world production of processed foods and beverages and $14 \%$ of employment as early as 2002 (Ayadi et al., 2006). Figure 1 shows the distribution of major food and beverages MNEs by home country of the parent in 2007. Most of these companies were based in the Triad, while companies that originated in the BRICS and other developing countries accounted for a small share of the total. According to this source, JBSwift Co. (Brazil), a producer of pork, ranked

\footnotetext{
${ }^{9}$ Western Europe, the US and Japan
} 
$36^{\text {th }}$ in the list of the Top 100; Noble Goup (HK), a grain processor ranked 55th; and InBev, the result of a merger between a Brazilian and a Belgian brewer ranked 12th and was the world's largest drink company after Coca-Cola (companies ranked by value of agro-food and beverages sales) ${ }^{10}$. However, many smaller food and beverages processors based in the BRICS have also internationalised (Nazareth Satyanand, 2011; Pozzobon, 2008) (Belik \& Rocha dos Santos, 2002). No doubt the panorama of the international food and beverage industry will change in the next few years with the presence of the new global players. ${ }^{10}$ In 2004 Am Bev, a Brazilian group, and Interbrew, a Belgian brewer, merged and created a
new group, InBev. However, the new company is based in Belgium, not in Brazil. 
Figure 1. The world's largest food and beverages MNEs, by home-country of the parent, 2007 (\% of companies)

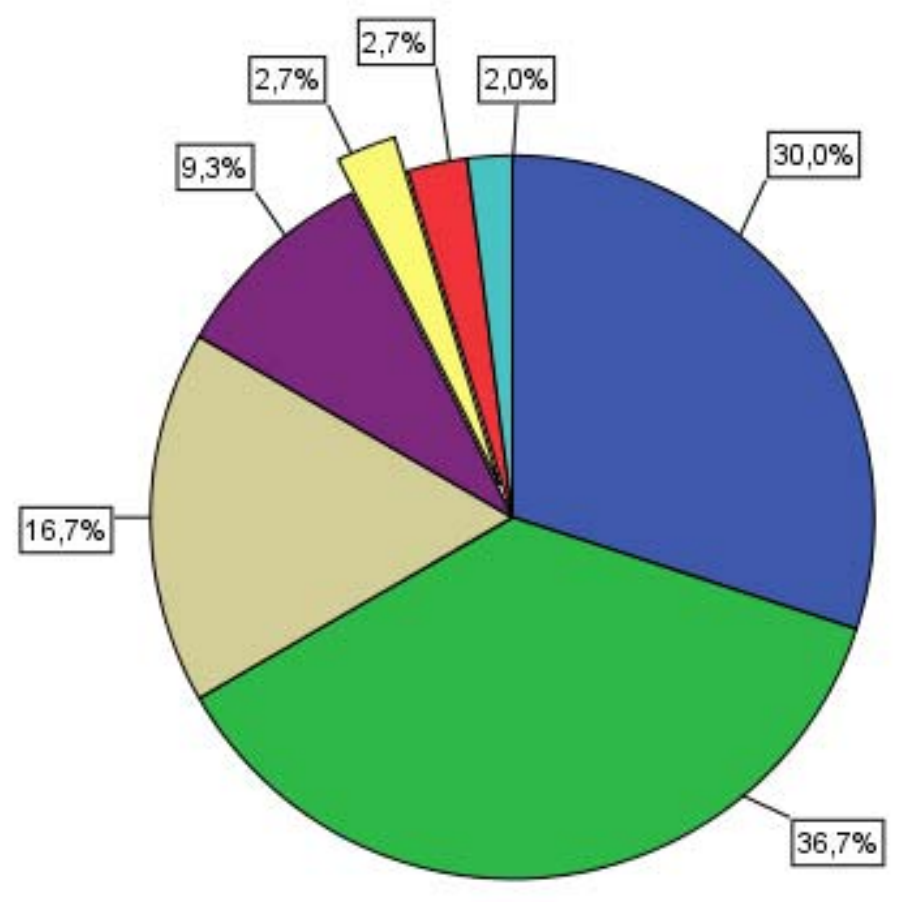

DUSA

$\square E U$

$\square$ Japan

Other developed $\square$ BRICS

$\square$ Developing countries

$\square$ Tax heavens

WORLD RANKING 2007

Source: Author's calculations based on AGRODATA 
Food and beverage MNEs have met considerable constraints and challenges in developed countries: stagnant demographics; an aging population; declining income elasticities with growing income levels; the new preferences of some consumers for fresh, organic and artisan products; the entry of large tobacco and pharmaceutical firms in F\&B markets; and lastly, competition from retailers' cheap own brands (Goodman, 2003; Schmidhuber \& Traill, 2006; Senauer, 1990; Tozanli, 2005; Wilkinson, 2002). However, the most important recipients of food and beverage FDI are still developed countries; they received 87\% of inward FDI stock in both 1990 and 2007 (UNCTAD, 2009). Furthermore, the evolution of food and beverage FDI flows from 1989-1991 to 2005-2007 shows that industrialised countries became increasingly important (from $67 \%$ to $84 \%$ of the total) during this period, despite the fact that inward food and beverage FDI flows received by developing economies, Southeast Europe ${ }^{11}$ and the CIS also grew.

Emerging economies with dynamic demographic trends and increasing consumer power such as the BRICS seem to be attractive to food and beverages MNEs (Tozanli 2005). Ayadi et al. (2006) studied the restructuring operations of the world's 100 largest food and beverage MNEs (thereafter, the Top 100) over 1998-2003, and noted that the companies that tended to invest in emerging markets also showed a tendency to divest in the Triad. According to the literature, food and beverages MNEs prefer countries with large internal markets, high GDP per capita, large urban populations, high levels of protection for these industries and easy availability of cheap inputs and raw materials; in addition, membership in a trade bloc is a plus (Ayadi et al., 2006; Gopinath et al., 1999; Pick \& Worth, 2005; Rama \& Wilkinson, 2008). Processes of urbanisation often contribute to changes in diet, with a transition from staple foods and grains, to more convenience foods and more animal protein (Caballero et al., 2011). By contrast, these companies are not especially interested in countries with low wage rates (Ayadi et al., 2006; Makki et al., 2004). In similar vein, an earlier study claimed that low wages had lost their prior importance in attracting food FDI to Brazil given the high capital intensity of the modern food industry (Belik, 1994).

\footnotetext{
${ }^{11}$ Albania, Bosnia and Herzegovina, Croatia, Montenegro, Serbia and the FYR of Macedonia.
} 
While the BRICS display large internal markets, quick processes of urbanisation and other of the above mentioned characteristics, preferences of food and beverage MNEs for host-countries with cultural or regional linkages with the home-country (F Filippaios \& Rama, 2011) may be a limitation in some cases since most of these firms are based in the West. The Uppsala school of thought proposes that MNEs follow a sequence from their home-base to countries with greater "psychic distance". The more dissimilar the home and the host-country are in terms of tastes, values, ethics, etc., the more difficult it will be for the MNE to operate and respond to local demand (Goerzen \& Beamish, 2003). Cultural distance may be accentuated in the case of food and beverages, which are culturally bound products. $42 \%$ of German agribusinesses interviewed by Heyder \& Theurvsen (2011) reported that they progressed slower than expected in the markets of the BRICS, a difficulty the author attributes to a cultural gap.

\section{Investing in the BRICS}

This section analyses trends of food industry FDI in the BRICS. Possible effects on concentration and competition in the host countries are discussed.

\subsection{US investment}

According to the Uppsala school of thought, the sequence of penetration into different markets proceeds according to cultural similarity with the homecountry of the MNE. This thesis implies a gradual approach regarding foreign expansion of these companies. The recent evolution of US food investment in BRICS seems to support this point of view.

Among the BRICS, Brazil was until recently the preferred location of US food and beverage FDI, followed at a distance by China (Figure 2). Between 1985 and 1995 alone, US investments in the Brazilian food industry tripled (Bolling et al., 1998). 
Figure 2

U.S. Direct Investment Abroad on a Historical-Cost Basis In the food industry of the BRICS

(Millions of US Dollars)

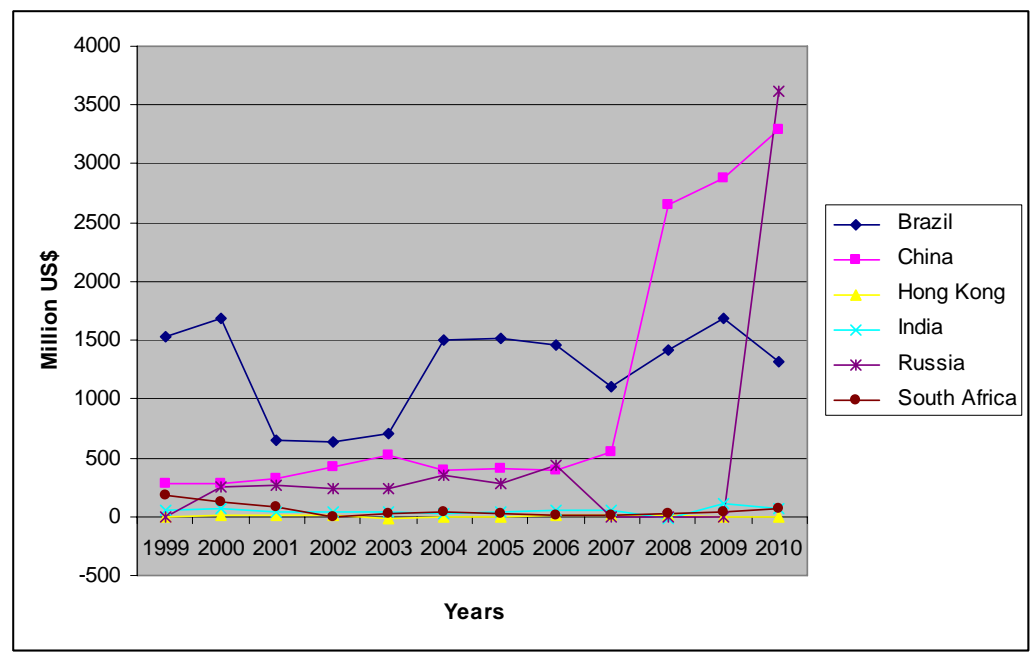

Source: Author's calculations based on Balance of Payments and Direct Investment Position Data, Survey of Current Business, 2012.

However, a geographic shift may be taking place since food and beverage US FDI grew less dynamically in Brazil than in China during the last period. By 2007-2010, China had become the most important destination of US outward FDI channelled to the food industries of the BRICS. Outward US food and beverage investment in BRICS may be changing, following patterns explained by the above mentioned theory. Initially attracted to countries in the Western Hemisphere, US food and beverage MNEs may be looking now to more distant, unfamiliar locations for investment.

Increasing familiarity of US companies with the Chinese food market is a possible explanation for this shift. Actually, an analysis published at the end of the 1990s attributed the low level of US FDI in China's processed food industry to "the short history of FDI in general in China" (Bolling et al., not dated, p.83). As shown by these authors, high tariff barriers and transportation costs have probably been additional stimuli to US food FDI in China. Their econometric model suggests that US food companies view FDI as a means to entering the subsectors of the Chinese food industry where trade was not economically feasible (concentration level, exports, imports and market size also checked). Even the removal of trade barriers, they claim, would leave very high 
transportation costs which would justify the interest of US food companies in local manufacturing instead. Given the relatively low value-added of food products, transportation costs are comparatively high. Their study supports the contention of another econometric model, which proposes that foreign sales and exports are substitutes in the US processed food industry (Gopinath et al., 1999). The discussion suggests that the main objective of US food and beverage investors in the BRICS is likely to be their respective domestic markets, not exports.

\subsection{EU investment}

Again, the importance of physical or cultural proximity is apparent. EU food, beverage and tobacco companies prefer to locate their foreign affiliates in Russia ${ }^{12}$ and, especially, in Brazil, their most important destiny among the BRICS $^{13}$ (Figure 3). In each of the recipient countries, the most important EU food, beverage and tobacco investor has been the Netherlands. According to EUROSTSAT, in 2009, it accounted for $18 \%$ of the total EU food FDI position in Brazil, 13\% in China (54\% in Hong Kong), $8 \%$ in India and 29\% in Russia. EU investors based in other source countries are mainly involved in the food, beverage and tobacco industries of specific host-countries; for instance, Germany in Russia, and the UK in Russia and China. In turn, French food investors invest mainly in Brazil. Planning to enter the Brazilian market, the German agribusiness surveyed by Heyder \& Theuvsen (2011) claimed that finding expatriate managers fluent in Portuguese was a major difficulty. Given that both Portuguese and French are Latin languages, cultural proximity is probably an advantage for French food firms investing in Brazil.

\footnotetext{
12 In 2008-2009, however, EU investment in the food and beverage industry of Russia tended to decrease while investment in the other food and beverage industries increased.

${ }^{13}$ EUROSTAT Financial Account, Direct Investment Abroad of EU-27 provides no data on EU investment in the manufacture of food products, beverages and tobacco products in South Africa in 2008 and 2009 (last up-date 03-05-2012).
} 
Figure 3. EU direct investment position in manufacture of food, beverages and tobacco. BRICS, 2008-2009 (in million €)

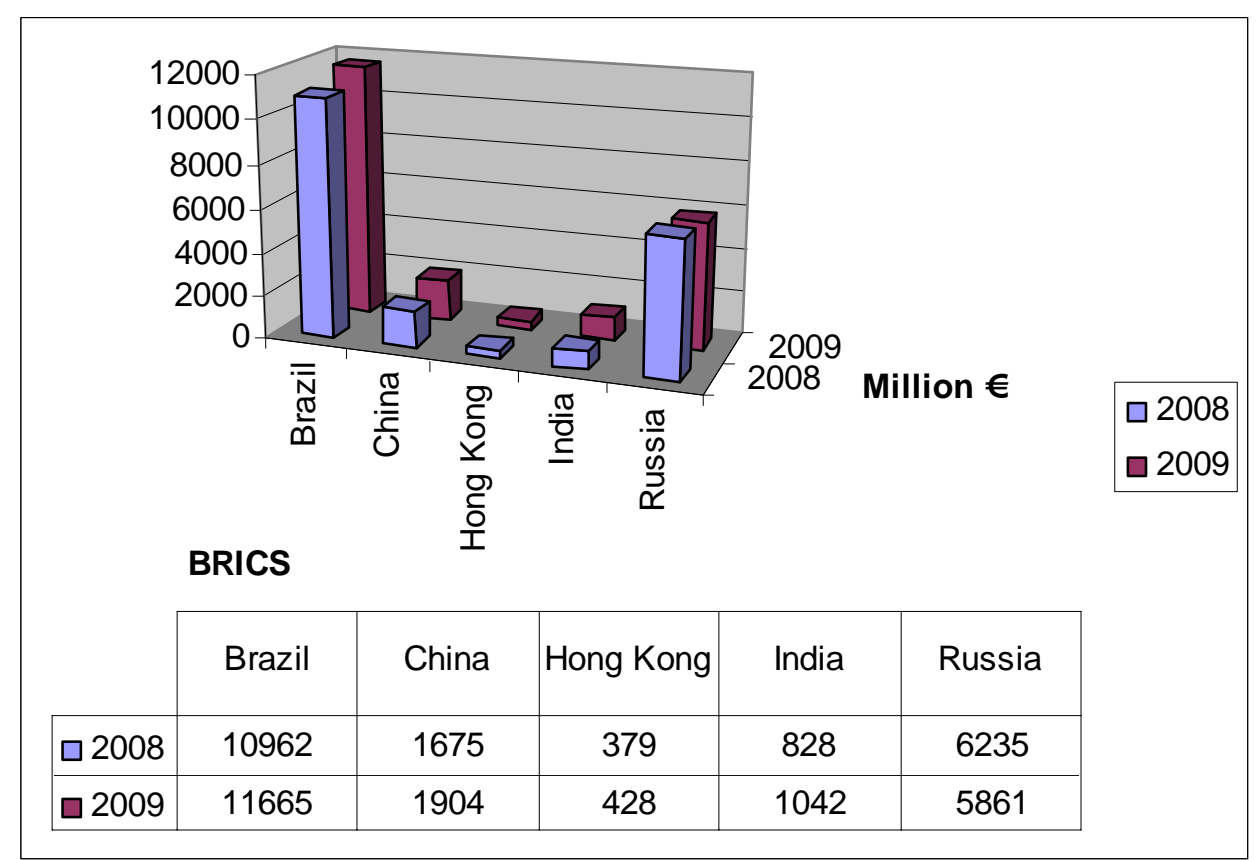

Source: Author's calculations based on EUROSTAT, Financial Account, Direct Investment Abroad of EU-27

Though their data are not disclosed by EUROSTAT, owing either to data protection or to their relatively smaller investments, other EU investors also play some role in specific subsectors of the F\&B industry of BRICS; for instance, the Spanish Campofrío and the Finn PIT in the processed meat markets of, respectively, Moscow and St. Petersburg (Berkum et al., 2007).

\subsection{Japanese investment}

Augustin-Jean (2006) argues that the data provided by the Ministry of Finance (Japan) underestimates Japanese investment in the agro-food industries of China, since they cover only large projects of more than 100 million Yen ${ }^{14}$. Given that I use those data in the following paragraphs, the results of the analysis should be taken with caution.

Japan food FDI in the BRICS needs to be analysed in the light of general changes in Japan's FDI in the world's food industry. In the 1970s and 1980s the weight of Japanese MNEs in the Top 100 increased (Tozanli, 2005). According to

\footnotetext{
${ }^{14} 30$ million Yen before 1993.
} 
this author, changes in international trade rules are a possible explanation. The new international norms stimulated Japanese companies to go global for the first time. The companies profited from trade liberalisation to produce food abroad for re-exporting to the home-market, a strategy still important in the main hostcountries for Japan food FDI -- China and Brazil (Agustin-Jean, 2006; Rama \& Wilkinson, 2012). Facilitated by the re-evaluation of the yen, international expansion was crucial for Japanese food companies, especially SMEs, given the saturation of the domestic food market at that time (Augustin-Jean, 2006).

By 1994-1996, outward Japanese FDI in the food processing industry amounted to 2,967 (in 000 Million Y). In 1997-1999, these investments increased to 18,960 to be reduced to only 1,588 in $2000-2002$ and to 1,653 in $2003-2004^{15}$. According to the same source, decreases continued in subsequent years, especially concerning Japanese investments in the Asian food industry ${ }^{16}$. The evidence seems to support results of previous research. Analysing the Top 100, Tozanli (2005, p.19) notes a retreat of the large Japanese food and beverage MNEs toward the domestic market, a trend characterised by the author as "an evolutionary path counter to the general trend" [of the Top 100].

Figures $4 \mathrm{~A}$ and $4 \mathrm{~B}$ show the evolution of outward Japan food FDI in the BRICS, both in terms of the number of projects and their value. Figures $5 \mathrm{~A}$ and 5B provide detailed information of those investments by host-country. As stated, the preferred locations within the BRICS are China and, well behind, Brazil; the other countries are much less important both in terms of the number of projects and their value. Foreign food investors initially adopted a cautious strategy, preferring to start their activities in China with small projects, which enabled them to learn about the Chinese market, quite new to them, and to avoid risk; Japanese food investors were no exception (Rama, 1992). This explains the great number of 1989-1993 projects and the fall of the number of 1994-2004 projects (Figure $5 \mathrm{~A}$ ); as well as the relatively low value of investments in the first period ( Figure $5 B)$.

\footnotetext{
15 Japan Ministry of Finance, Balance of Payment (www.mof.go.jp/english). July 2012

${ }^{16}$ Data by sector (country level) are not available for the last period and, therefore, I am unable to assess whether this new situation affected BRICS.
} 
Figure 4 A. Japan outward FDI in the food processing industry. Total BRICS, No. of projects

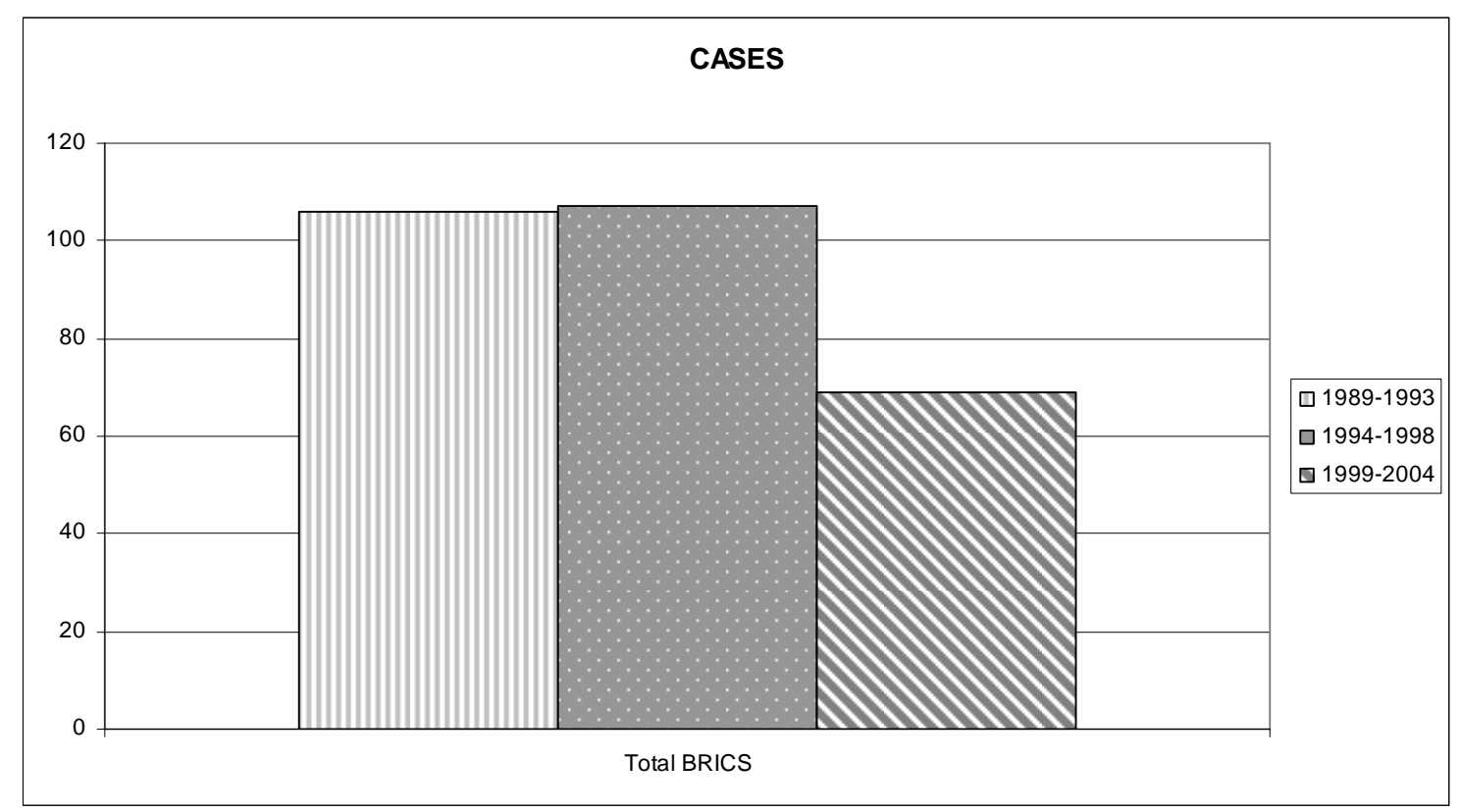

Figure $4 \mathrm{~B}$. Japan outward FDI in the food processing industry. Total BRICS, value (Y 000 Million)

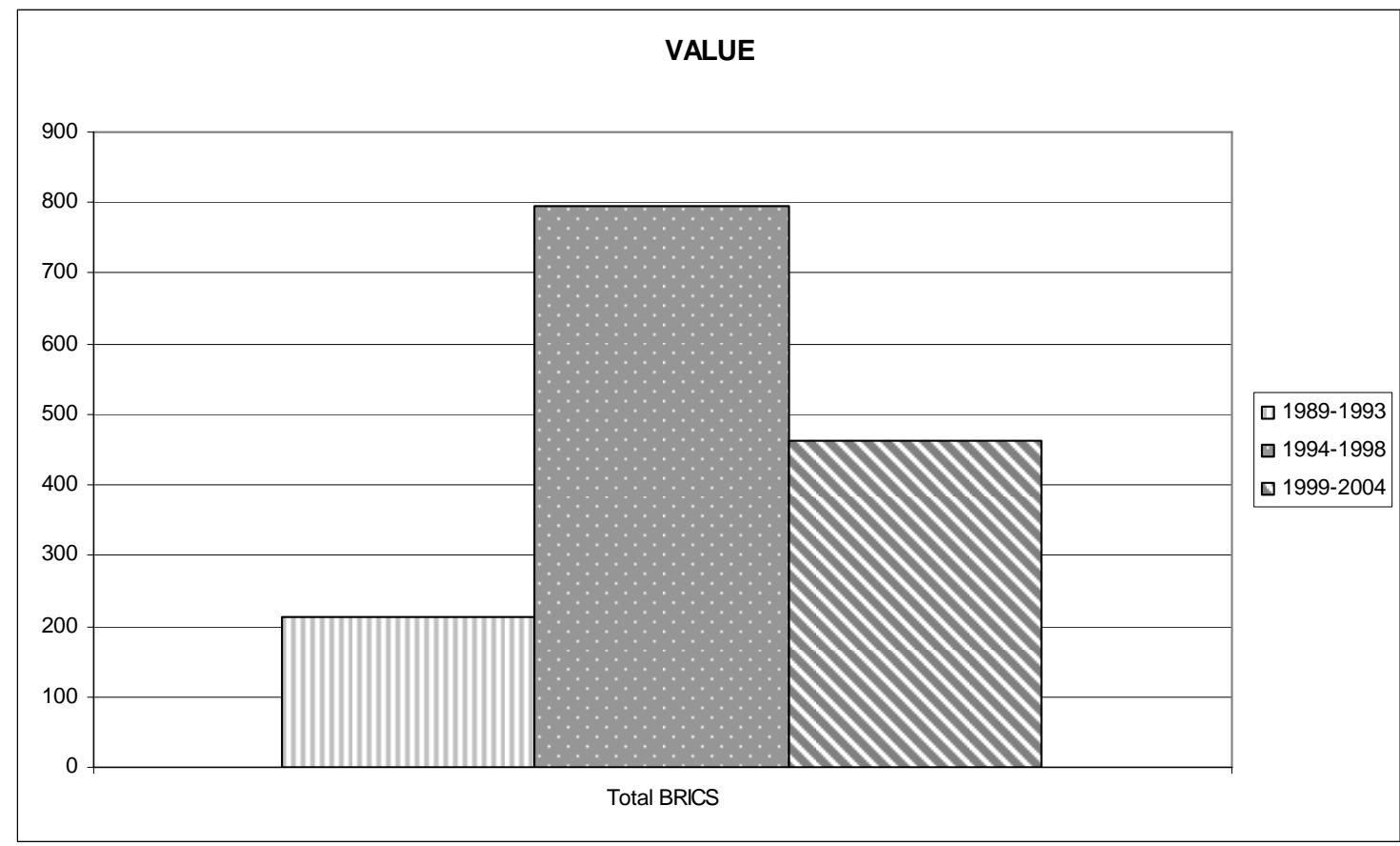

Source: Author's calculations based on data from Japan's Ministry of Finance. Balance of Payment (www.mof.go.jp/english). July 2012. 
Figure $5 \mathrm{~A}$. Japan outward FDI in the food processing industry, by country No. of projects

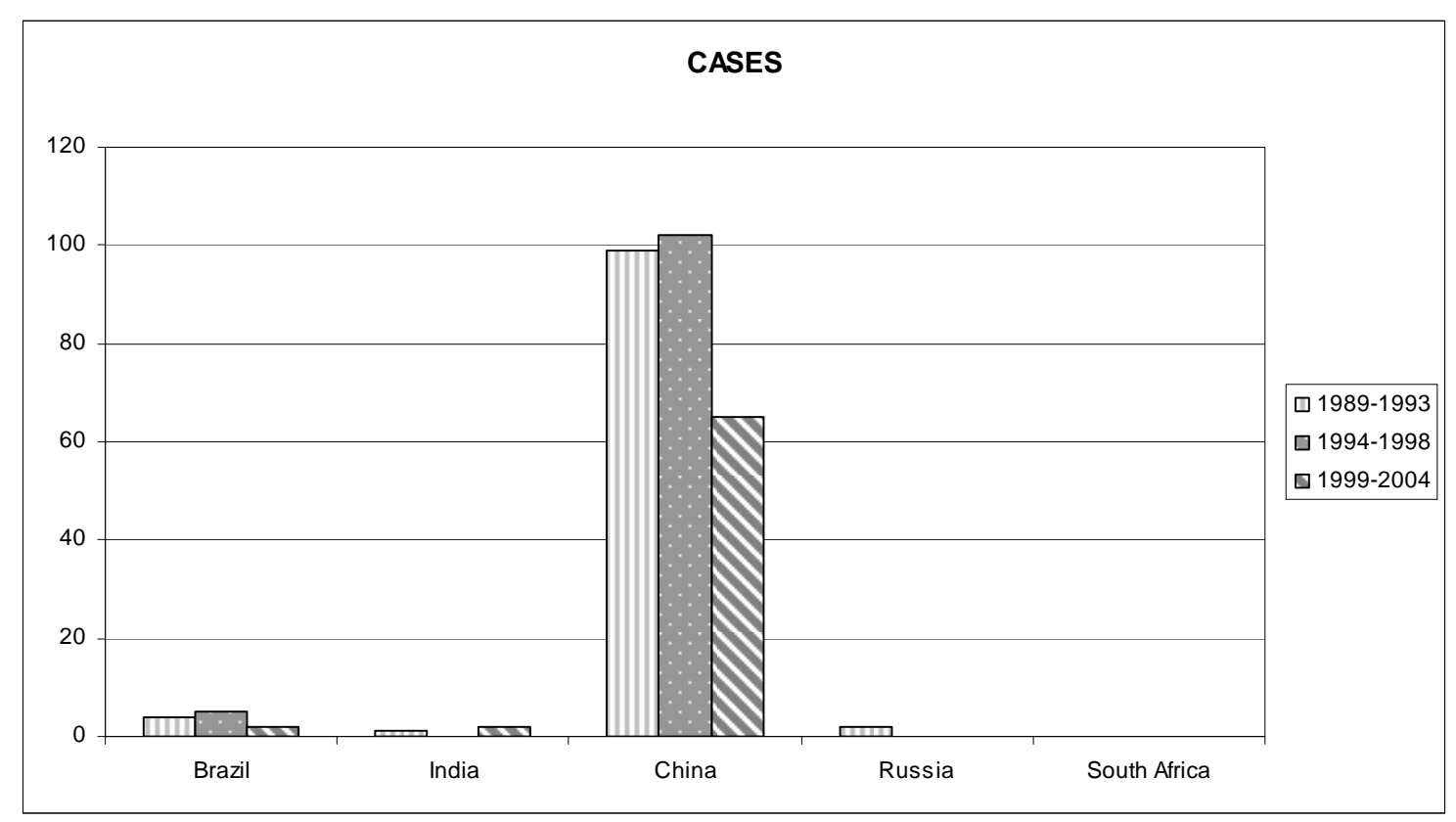

Figure $5 \mathrm{~B}$. Japan outward FDI in the food processing industry, by country Value (Y 000 Million)

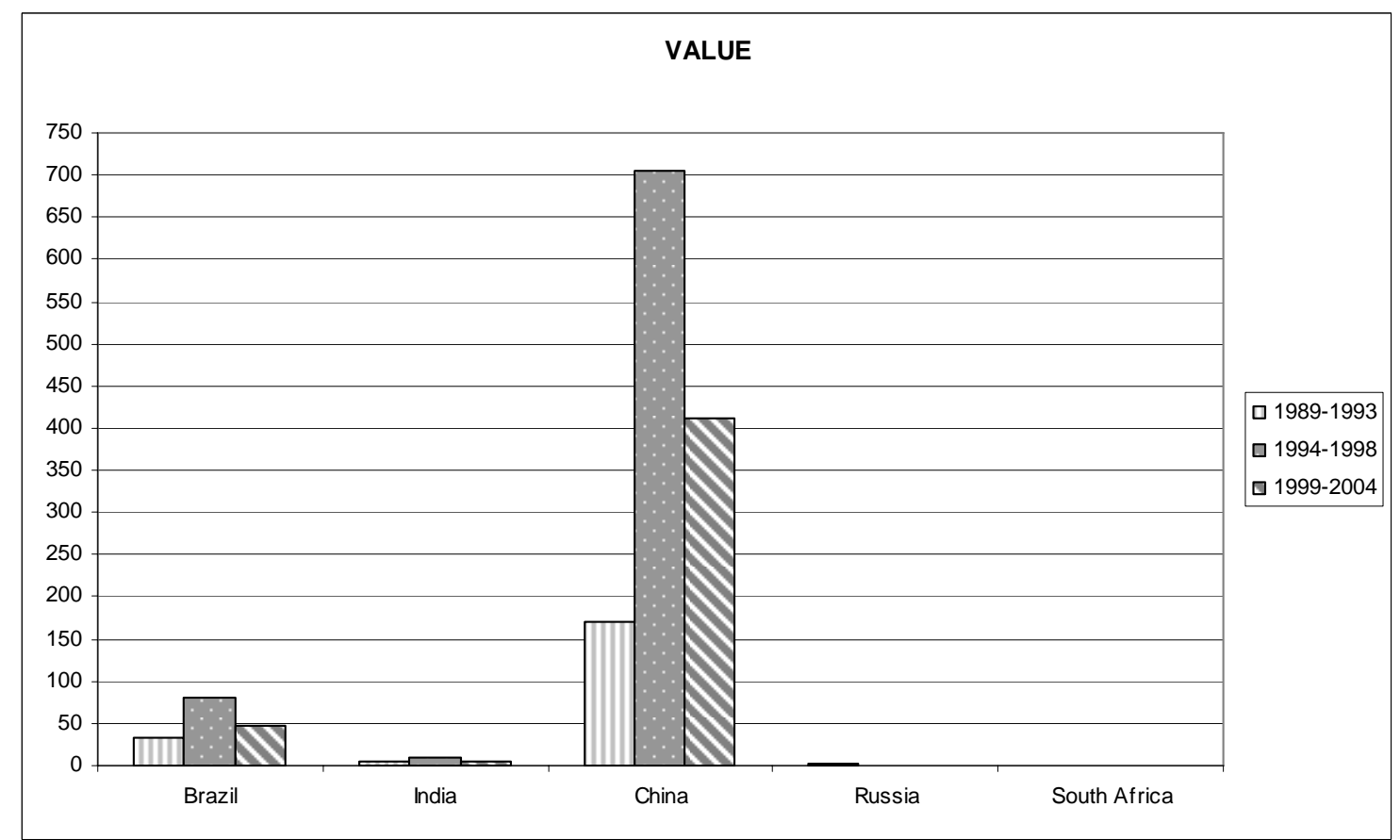

Source: Author's calculations based on data from Japan's Ministry of Finance. Balance of Payment (www.mof.go.jp/english). July 2012. 
Augustin-Jean (2006) emphasises the role of common values, trust, networks, social capital, and ethnic and cultural ties in the expansion of Japanese agro-food firms in China. The Japanese companies build strategic alliances with "overseas Chinese" in order to better understand the food tastes of consumers in mainland China. Augustin-Jean (2006) identifies three different types of strategies: i) a group of Japanese food firms sees China as the base for obtaining food supplies which are marketed both in Japan and all over the world; ii) Japanese SMEs almost exclusively market their foodstuffs in the home market; and finally, iii) a third group is involved in joint-ventures with partners based in China or in newly industrialised Asian countries, but these Japanese MNEs also strongly interact with local upstream industries. According to this study, Japanese investors remain in control of food supplies to the home-country; by contrast, they often need to collaborate with Western firms and with regional investors (e.g. Taiwanese firms) when they engage in food and drink processing, and in distribution in the host-country market.

Ethnical and cultural linkages with Japanese emigrants and their families have also played some role in the expansion of Japanese companies in agro-food in Brazil (Rama \& Wilkinson, 2012).

To summarise, these investments seem likely to provide access to export markets and create linkages with domestic actors.

\subsection{Smaller investors}

Companies based in the above countries are not the sole F\&B companies investing in the BRICS, nor are major food and beverage MNEs the only investors operating there.

Many foreign investors that are active in the Brazilian F\&B industry are smaller, regional investors (Farina \& Viegas, 2005). In South Africa, MNEs operating in consumer goods such as food and beverages are mainly small and medium sized (SMEs) European companies that are starting to expand in developing countries (Gelb \& Black, 2004). However, major F\&B companies, such as Unilever (The Netherlands-UK), Nestlé (Switzerland), Coca-Cola (US) or Danone (France), also have a presence in South Africa. 
In China, the phase of the "open door policy" in the food industry and agriculture attracted mainly SMEs from Hong Kong and Macao (Rama, 1992). Their operations in China were facilitated by geographical proximity, common language and common culture. By the mid-1980s, the contribution of industrialised countries to this industry consisted mainly of small Japanese ventures. As stated above, Japanese SMEs are still important in the agro-food industries of China (Augustin-Jean, 2006). In turn, smaller European investors have demonstrated an interest in the Russian F\&B industry (Berkum et al., 2007; Heyder \& Theuvsen, 2011).

As will be seen below, those smaller companies may play some role to fuel competition in the F\&B markets of the BRICS.

\subsection{Comparing the BRICS}

Quantitative comparisons of food and beverage FDI between the BRICS are rendered unreliable by the use of different currencies, different reporting bases for projects and even different definitions of the industry. For instance, EUROSTAT provides aggregated statistics for food, beverage and tobacco, while other investor countries do not include tobacco in these statistics. Also, hostcountries may use different statistical methods for reporting FDI (on Russia see, for instance, Berkum et al., 2007). In order to compare the situation in the BRICS, we use AGRODATA as a common source of information. According to this source, the BRICS accounted for nearly $12 \%$ of the total number of foreign affiliates of the Top 100 in $2002^{17}$. To put this figure into perspective, note that the rest of the developing countries accounted for $24 \%$ of total the same year.

Most of the foreign food and beverage affiliates located in the BRICS belonged to large companies based in the US, the EU and Japan, in this order of importance (Figure 6). The only country where the presence of EU affiliates surpassed that of US affiliates was Russia. Within-group investment, i.e. the BRICS' foreign affiliates located in other BRICS, accounted for around 4\% of the foreign F\&B affiliates operating in those nations. Most of them are the Chinese affiliates of a South African brewer.

\footnotetext{
${ }^{17}$ Last available year.
} 
Figure 6. Distribution of the foreign affiliates of major food and beverages MNEs, by home country of the parent (\%).
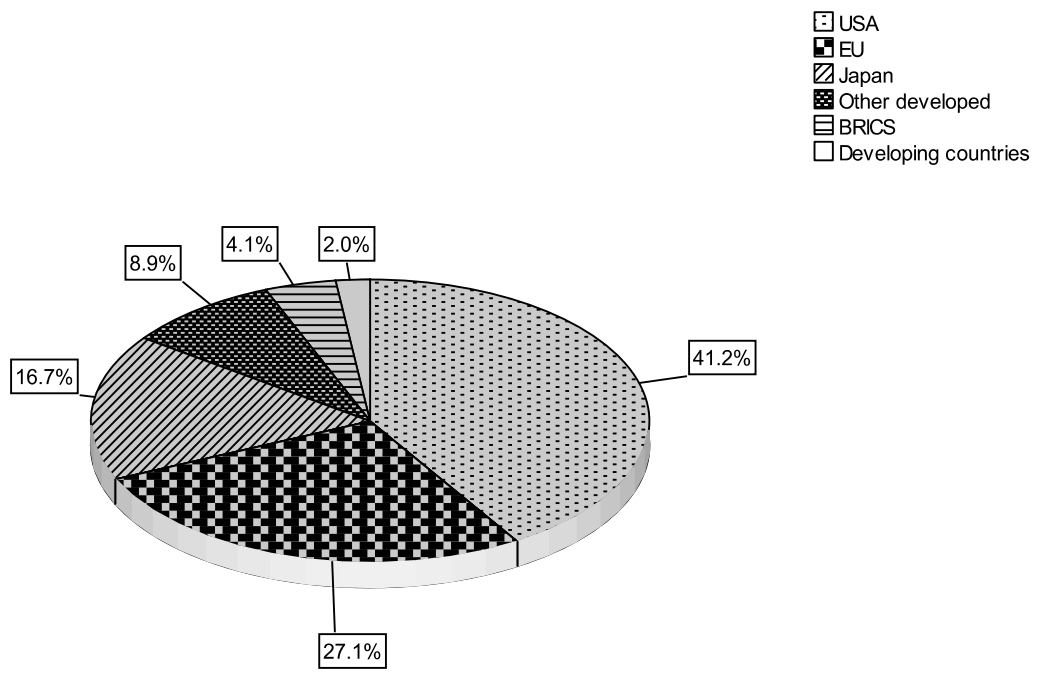

Source: Author's calculations based on AGRODATA. 
In each of the host-countries, the distribution of the affiliates by homecountry of the parent corroborates the importance of physical and cultural proximity (figures available upon request). In Russia, for instance, F\&B affiliates pertaining to companies based in the EU are the majority. In China, F\&B affiliates belonging to Japanese companies amount to $26.8 \%$ (while they account for only $16.7 \%$ on average in the BRICS).

Data on the distribution of affiliates provide valuable information on the consolidated position of F\&B MNEs over the years. This is an important consideration since F\&B MNEs internationalised quite early (Stopford \& Dunning, 1983) and many of their affiliates have operated for decades in some of the BRICS. The evidence suggests that the most important recipients of foreign F\&B affiliates are China, followed by far by Brazil (Figure 7). India, Russia and South Africa host each less than $10 \%$ of the foreign F\&B affiliates located in the BRICS. 
Figure 7. Distribution of the foreign affiliates of major food and beverages MNEs, by host country. BRICS

\section{BRICS}

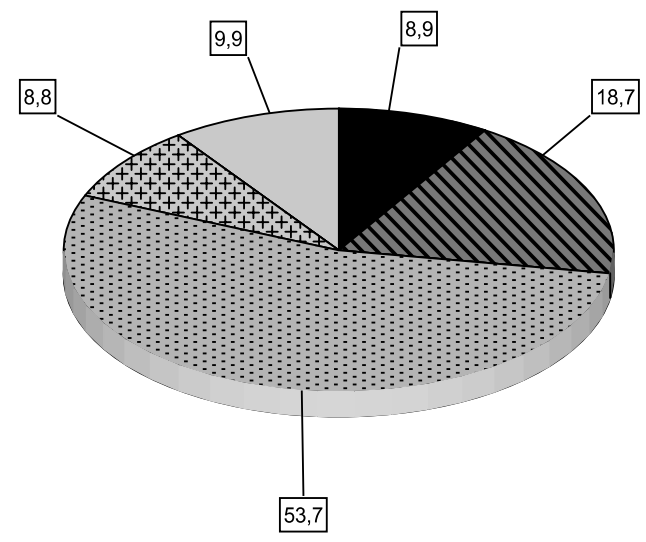

Source: Author's calculations based on AGRODATA

Complementary information on the restructuring operations of these companies can help us to understand recent trends. To include mergers and acquisitions (M\&A) in the analysis is crucial, since most food and beverage FDI is currently coming from M\&A (not from greenfield investment) (Tozanli, 2005). Case studies report that $M \& A$ has been a very important mode of entry, for instance, in the Brazilian F\&B market (Farina \& Viegas, 2005). Consequently, I study the behaviour of MNEs using a database comprising 3,507 restructuring operations undertaken by the Top 100 from $1987-2003^{18}$. From this database, I select 330 cross-border operations whose target nations are the BRICS (definition below).

Consideration of a long period is essential for capturing this relevant information. M\&A include "takeovers and related issues of corporate restructuring, corporate control and changes in the ownership structure of firms"

\footnotetext{
${ }^{18}$ Last available year (AGRODATA).
} 
(Copeland \& Weston, 1992, p. 676). An acquisition occurs when a firm takes a controlling ownership interest in another company, a subsidiary of another company, or assets of another company such as a brand name. Consequently, an acquisition may involve the purchase of another firm's assets or stock, with the acquired company continuing to exist as a legally owned subsidiary. Here, the operations include purchases of companies or subsidiaries, acquisitions of brand names, takeovers and joint-ventures (JV).

The database includes the following data: date of the transaction, name and home-country of the purchaser, name and home-country of the seller, and name and location of the targeted company (or affiliate). The home-country of the seller and the target nation, i.e. the location of the acquired company (or subsidiary), may differ. For instance, a German MNE may acquire a Brazilian affiliate owned by a US MNE in order to penetrate into the Latin American food market. In this case, the targeted nation is Brazil.

Figure 8 shows a group of nations - India, Russia and South Africa -where the number of operations performed by the world's largest food and beverage MNEs during the period was relatively stable. In India, there was initially some growth in the number of projects induced by a new regulation promulgated in the mid-1980s, more favourable to FDI. However, the figures show that the impact of the new regulation was probably more qualitative than quantitative, as the number of operations was not very high, but the new regulation appeared to be successful in attracting FDI to subsectors where its effects were considered beneficial (e.g. fish and meat processing) (Rama, 1992). At the same time, the number of foreign projects associated with export obligations, an important goal for the Indian government rose steadily in those industries. A study claims that, though the government encourages FDI in food and beverages, South Africa has not been very successful in attracting such investments in recent years owing to distance from the rest of the world's large markets, the relatively small size of the domestic market and an already important presence of food and beverage MNEs (Baskaran \& Muchie, 2008). 
Figure 8. Restructuring operations of major food and beverage MNEs, by year and target country. BRICS

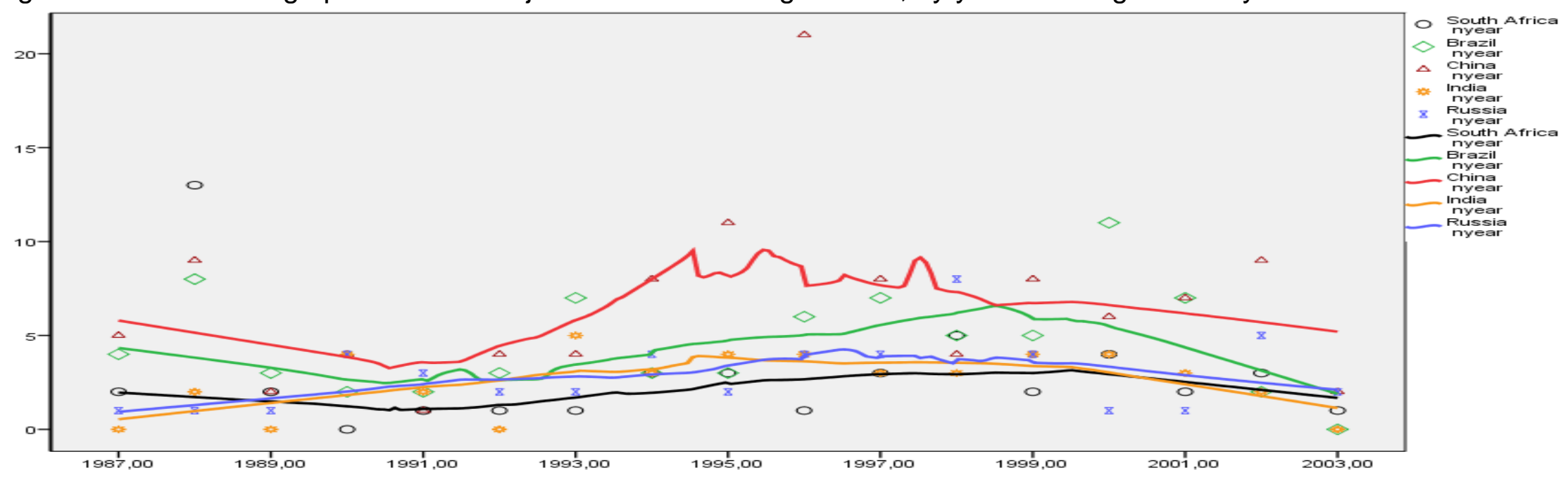

Source: Author's calculations based on AGRODATA 
Operations in Brazil and, especially in China, were much more numerous than in the above mentioned nations during the period examined, and their rate of growth was more dynamic. In Brazil, liberalisation of investment laws and membership in MERCOSUR, the regional trade pact, stimulated food and beverage FDI by the mid 1990s (Farina \& Viegas, 2005). Moreover, these authors argue, controlling for inflation, the Plan Real by that time stimulated the demand for food, and this circumstance, in turn, encouraged the entry and expansion of MNEs in the Brazilian market for processed food and beverages. Family companies in difficulties were often the target of $M \& A$. However, by 1995, the number of operations whose target was Brazil tended to decrease, reaching the levels of India, Russia or South Africa (Figure 8). Farina and Viegas (2005) point to several reasons for this, such as fierce competition in those Brazilian markets and concentrated income distribution. In spite of better living conditions that promoted a more varied diet, these authors claim that the distribution of income in Brazil is still highly unequal. This situation may slow down the development of the modern F\&B industry and the expansion of MNEs, unless the consumer base is expanded as in industrialised countries.

The great number of operations in China probably reflect the fact that initially projects were small, even those of the world's largest food and beverage MNEs, because by the 1990s these companies still were investing in China on an exploratory basis ${ }^{19}$ (Rama, 1992). The large food and beverage MNES could not afford not to be in China, given the presence of their international rivals there. The projects represented a small risk for these firms, enabling them to acquire valuable experience in the Chinese market. They were later followed by more important concerns. These firms approached the Chinese market gradually ${ }^{20}$ because they feared political risk and, at the same time, most of them felt they were unable to comply with the export goals of the government; their most important motivation was, instead, China's large domestic market.

\footnotetext{
${ }^{19}$ For instance, Tate \& Lyle (UK) entered the Chinese tea market with a US $\$ 450,000$ investment in 1987(Rama, 1992).

${ }^{20}$ This point of view is confirmed by Augustin-Jean (2006) for the specific case of Japanese agro-food investors operating in China. Chambers of commerce and other Japanese institutions that had been collecting information on the Chinese market well in advance of agro-food investments taking place played an important role in guaranteeing the subsequent success of those investors in the host-country.
} 


\subsection{Concentration, competition and limitations}

After reviewing the empirical literature, Caves (1996) concludes that MNEs, in both developed and developing countries, are likely to be found in non competitive markets. Food and beverages MNEs are not an exception. These companies are more likely to concentrate in markets for branded, differentiated foodstuffs, where advertisement plays a significant role. They tend to invest in high valued-added segments of this industry. According to "Melhores e Maiores" statistics on the 1,000 largest companies operating in Brazil, the share of food MNES in the total sales of large food companies fell from 32\% in 1993 to $25 \%$ in 2009 (da Silva, 2011). However, these figures may underestimate the importance of MNEs in specific Brazilian food markets, as within industries there is sometimes a division of labour between domestic firms and foreign firms. For instance, in Brazil, regional cooperatives control the market for milk and butter while MNEs such as Nestlé, Danone, Bongrain, etc. control that of other dairy products with higher value-added (Wilkinson, 2006). This suggests that concentration of MNEs may be quite high concerning, for instance, specific dairy products. By the end of the 1990s, sales of US food affiliates in Brazil were concentrated in cookies, biscuits, orange juice, soft drinks, canned and frozen fruits and vegetables, oilseeds, breakfast cereals, and beer (Bolling et al., 1998).

Similarly, Berkum (2007) reports that foreign investors control a large share of specific Russian food markets (for instance, more than $50 \%$ in confectionary). In India, foreign penetration in consumer goods was as high as $67 \%$ of total sales as early as the end of the 1990s (Franco et al., 2011). Bolling et al (not dated) sudied a panel of 43 food industries in China and observed that US food and beverages MNEs were more likely to operate where the market was highly concentrated among a few firms in the beer, vegetable oil and wet corn milling industries. Their findings are supported for all MNEs operating in the food and beverages industries of China, irrespectively of the nationality of the parent (Wei \& Cacho, 2001). To summarise, these companies seem to be contributing to concentration of specific $F \& B$ beverages markets in 
the BRICS. What are the effects of their strategies on competition in F\&B markets?

After reviewing the literature, Blomström and Kokko (1996) conclude that there is a larger risk that MNEs crowd out local firms in developing countries than in developed countries. However, studies on the BRICS suggest that food and beverage MNEs may lose market share to domestic firms able to sell reasonably priced good quality products. A study reports that, from 1998 to 2000 alone, the leading brands out of 157 categories of products lost market share in Brazil (Farina \& Viegas, 2005). MNEs such as Kellog's (US) and Nestlé (Swiss) lost market share in breakfast cereals and powdered chocolate owing to the emergence, the authors report, of little-known brand names, most of them marketed by domestic firms. Brazilian consumers preferred those products owing to lower prices coupled to acceptable quality. By the same token, many consumers in Brazil and elsewhere in Latin America have preferred inexpensive sodas and beverages made from fruits to the soft drinks marketed by leading MNEs (ECLAC, 2005). According to a report, Russian consumers prefer local foodstuffs, which are considered better value for money and healthier (Berkum et al., 2007). The case of China is particularly interesting (Wei \& Cacho, 2001) because it shows the effects of competition between different types of foreign F\&B investors. As noted by these authors, many large MNEs entered in the 1990s the high-income consumer sector for food and beverages. Regional, smaller food and beverages MNEs based in Indonesia, Malaysia, Thailand and Taiwan, instead, positioned themselves in the middleincome segment that is crucial for market expansion. Competition, these authors argue, was strengthened since at the same time domestic firms learned from foreign investors concerning quality standards and developing competitive brands. Their findings seem to support those of Buckley at al (2007) who suggest that small overseas Chinese firms, in mature industries of China, are able to contribute marketing skills in standardized goods, though not state-ofthe art technology to produce differentiated products.

Fast market growth has often stimulated the emergence of strong domestic firms in the BRICS, while policies are also playing some role. For instance, the Brazilian government strongly supported the recent merger of two very large rival firms active in the international meat processing sector, Sadia 
and Perdigão ${ }^{21}$. Unlikely in other developing countries, in the BRICS, food and beverages MNEs often compete with large state-owned companies (China or Russia) or with companies financed by a large development bank (Brazil). These characteristics of the industry of host-countries could counterbalance the market power of foreign food and beverages MNEs in the BRICS.

The substantial presence of food and beverage MNEs in the BRICS does not mean that the companies face no difficulties in those markets. Few studies survey the same sample of foreign food firms in order to detect possible difficulties that may discourage FDI in the BRICS; this gap in the literature makes comparisons difficult. An exception is Heyder and Theuvsen's (2011) study, especially interesting because it reports on the difficulties of new entrants (not incumbents) in those markets. German agro-food companies aiming to enter the markets of the BRICS, they report, encounter the following problems: In Brazil: finding skilled workers and good expatriate managers fluent in Portuguese; in Russia: corruption and bureaucracy; in India: quality control, corruption, and tariff and non tariff barriers, and in China: lack of legal security and intellectual property rights (IPR).

Other authors focus on difficulties encountered by foreign investors in food in specific countries. According to a survey, good performance, i.e. the meeting of expectations of food and beverage foreign affiliates was below average in South Africa (33\% versus $46 \%$ of affiliates in all sectors)(Gelb \& Black, 2004). The food and beverage affiliates surveyed by the authors believe the situation in South Africa has deteriorated concerning the official environment (e.g. real estate, the obtaining of visas, law enforcement) and the availability of suitable inputs, with some exceptions such as telecom services. In spite of generalised optimism about the expansion of the Russian food markets, both domestic and foreign agro-food firms operating there complained of the increase of food imports, the strengthening of the ruble, which stimulates import competition, high pricing of energy supplies and railway transport, the complexity of the tax system, insufficient road infrastructure in rural areas, insufficient development of agriculture education and research, and an unclear land property right system (Berkum et al., 2007). Dutch agro-food

\footnotetext{
${ }^{21}$ The Economist, January 21st-27th 2012, special report on "State Capitalism".
} 
entrepreneurs mention bureaucracy, in addition to the difficulty of the Russian language (Berkum et al., 2007).

The modern F\&B industry depends on modern distribution channels, not always in place in developing countries, especially in their small cities and rural areas. Insufficient development of modern retailing facilities hampered the expansion of large F\&B companies, especially MNEs, even in an agriculture rich country such as Argentina (CEPAL, 1983; Geroski \& Vlassopoulos, 1991). The reason is that foodstuffs and beverages marketed by those firms often require, for optimal consumption conditions, refrigeration facilities and transportation (e.g dairy products, pre prepared food, soft drinks) or frequent substitution in the shelves of retailers (e.g., cookies, packaged bread, confectionary products). With the exception of the most affluent neighbourhoods, these facilities are often unavailable in certain developing countries. These circumstances may also limit the capacity of some developing countries to attract FDI to their F\&B industry.

Penetration of foreign supermarkets in BRICS took place at different times. According to Reardon et al (2004), the take-off of supermarkets occurred half a decade later in countries with previously state-controlled economies, such as China, as compared to South America, but is now moving very fast. A reason for quick growth, they explain, is that state-managed retail chains had already weakened much of the traditional retailing system. Moreover, they argue, while in Brazil there is a legislation protecting wet markets, in China those markets have been integrated into supermarket chains. In Russia, there are several foreign retailers (Metro, Spar, Auchan, Carrefour, Migros Türk); among the top five grocery retailers two are Western and three are Russian (Berkum et al., 2007). In China, foreign investment in retail chains were authorised in 1992; in India, only in 2011 (Dasgupta, 2011). In India, it is claimed that foreign retailers may potentially contribute to improve the efficiency of the supply chain in agriculture, characterised now by a poor distribution network and substantial losses of fresh products; however, concerns about the possibility of monopoly power of foreign entrants, manipulation of prices or the destruction of the informal indigenous retail sector have also been expressed (Dasgupta, 2011). Early expansion of supermarkets, both foreign and domestic, (Belik \& Rocha dos Santos, 2002) has probably stimulated the entry of MNEs to 
the Brazilian F\&B industry. According to Farina and Viegas' (2005) research, this expansion has also accrued benefits to the Brazilian consumer by introducing downward pressure on prices of the F\&B industry.

\section{Are food and beverage MNEs embedded in the BRICS?}

The concept of embeddedness implies that contacts of the subsidiary with local actors become more relevant not only in business but technology as well (Gassler \& Nones, 2008). Therefore, the affiliate depends more on ties with the local environment. Embedded affiliates interact with other actors who operate in the host environment (Meyer et al., 2011).

Linkages between MNEs and domestic firms can create spillovers in the host-country economy and play an important role in the catching up processes of late industrialised countries, such as the BRICS. However, an important condition is the embeddedness of affiliates in the local economy, which in turn depends on several factors: the familiarity of the affiliate with the local "milieu", its business relationships with local partners and it willingness to perform R\&D, especially valuable forms of research, in the host-country. This section investigates whether food and beverage MNEs are embedded in the food and beverages industries of the BRICS. In doing so, I attempt to respond to three research questions.

Q 1: How long have the food affiliates been engaged in local production? Economic theory considers that experience in the host-country is a good predictor of the affiliates' ability for building local networks and acquiring social capital. Comparing India and Brazil, Franco et al (2011) propose that the age of the subsidiary is a good predictor of its acquaintance with local industry (e.g. local suppliers of capital goods).

Q2: How do the entry strategies of these MNEs contribute to their linking with local partners?

Q3: Do food and beverage MNEs perform R\&D in the host-country. And if yes, which types of innovative activities do they develop there?

\subsection{Acquaintance with the milieu}


As suggested by theory, affiliates are, "a priori", not endowed with social capital in the host country (Rugman, 2003), and time may be a crucial factor for allowing them to build local networks. Franco et al (2011) argue that since MNEs have a longer history in Brazil than in India, the possibilities for interactions with domestic firms may have been greater in the former. They also contend that, due to the larger and longer presence of MNEs in Brazil, technological inputs such as capital goods produced by local suppliers were more likely to be on par with international quality. Actually, they found that older affiliates were more likely to purchase Brazilian capital goods, interacting with domestic suppliers of technology. The discussion suggests that different periods of entry in different host-countries may influence affiliates' level of acquaintance with the local economy.

"Waves" of food FDI have taken place at very different periods of time in BRICS. This sub section shows that the business history of food and beverage MNEs has been longer and more continuous in Brazil than in any of the other countries studied here.

Food MNEs entered the Brazilian market in the 19th century (Amatucci \& Avrichir, 2008). Some of the world's largest food and beverage MNEs have been operating there for decades now; for instance, Unilever (1920) or Procter \& Gamble (1930). In the late 1940s and early 1950s, certain European agrofood companies saw in Latin America a sheltered area, given the US food firms' rapid penetration of European markets; according to Belik (1994) this was the birth of the modern processed food industry in Brazil. The primary objective of these investments was import-substitution.

South Africa has also hosted food and beverage MNEs for a long period of time, though many of the companies temporarily departed owing to the international campaign against apartheid (Gelb \& Black, 2004).

Certain large food and beverage MNEs have been doing business in India for decades ${ }^{22}$. However, it was not until the mid-1980s that the government promulgated for the first time a series of norms aimed at attracting FDI. Though the F\&B industry has not been, in principle, a priority, the Industrial Development Bank of India has financed certain inward FDI food

${ }^{22}$ This paragraph and the following draw on Rama (1992) 
projects (export projects, projects that use domestic inputs and projects that contribute new technology to the country) and food-packaging projects.

By contrast, the history of food and beverage MNEs in China and Russia is much more recent. In China, inward FDI has been assigned a role in China's development strategy since 1979 in the framework of an ambitious economic reform. The objective underlying regulation of inward FDI has been to experiment in geographically defined areas - i.e. the coastal provinces of Guangdong, Fujian and Shandong - with certain mechanisms used in market economies. As in other sectors, the early objectives of the government regarding inward FDI in the food industry were the earning of foreign currency and the acquisition of new technology. Food processors from Hong Kong, Macao and Japan were probably the most willing to comply with Chinese government export directions, as they had close direct linkages with traditional foreign markets for Chinese products.

Finally, in Russia, MNEs were not allowed to participate in the 1992 mass privatization of industries, as inward FDI was not considered an avenue to privatization for strategic and political considerations, particularly in regards to domestic natural resources (Ramamurti, 2008). However, by 2003-2008, food and tobacco already amounted to $4.4 \%$ of the FDI projects in Russia and, more specifically, $5.2 \%$ of those of the EU-15 (Hunya \& Stöllinger, 2009). After lagging behind other BRICS, FDI seems to be increasing quickly in food and beverages Russian markets. An important motivation of foreign investors has been high tariff barriers for imported foodstuffs and drinks (see Weiss's Chapter).

Though this is only a rough analysis of the degree of acquaintance with the local milieu, since there may be different "waves" of food FDI in the same country, the longer business history of food and beverage MNEs and their substantial, continuous presence in Brazil suggest that those companies may have developed more interactions with domestic companies there than in the rest of the BRICS.

However, as noted by Chobanova (2009), longer periods of investment do not always result in deeper embeddedness; the strategies of the companies should be studied to better understand their linkages with the local economy. 


\subsection{Modes of entry and partnerships with local actors}

An important aspect in this respect is the entry strategies of the firms. To study them, I use the above described database on restructuring operations of major food and beverages MNEs.

Greenfield investment contributes to the creation of new capital in the host-economy. However, this mode of entry has not been very popular with major investors which entered the food and beverages markets of the BRICS from the end of the 1980s to the early 2000 (Table 2). Moreover, China and Russia accounted for $80 \%$ of new industrial plant creation and for nearly $95 \%$ of new affiliate creation in this group of countries during the analysed period. The contribution of these investors to capital creation in the food and beverages industries of Brazil, India and South Africa seems to be very small.

Though other modes of entry do not promote capital creation they may, nevertheless, contribute to development of the host country since they could incentive linkages between foreign investors and local partners. I turn now to this question.

During the period covered, the most popular mode of entry in the food and beverage markets of the BRICS was the formation of joint ventures (JV), which accounted for $23.3 \%$ of the restructuring operations of the top group in those countries, closely followed by acquisitions, which were $21.5 \%$ of total. MNEs also used acquisitions of majority stakes in domestic firms (13.3\% of operations) and fusions of two affiliates pertaining to MNEs located in the BRICS (8.8\%). The acquisition of majority (or minority) stakes may be just a portfolio operation, not implying the involvement of the MNEs in the management of the company; therefore, it is likely to have less potential than JVs for interaction with local partners and the transmission of managerial practice to the local industry. The operations clearly implying collaboration with local partners (JVs and cooperation agreements) amounted to $27.8 \%$ of the total number of operations. 
Table 2. Restructuring operations of the world's 100 largest food and beverage MNEs, by type of operation. BRICS, 1987-2003 (in \%)

(number of operations in parenthesis)

\begin{tabular}{|l|r|r|r|r|r|c|}
\hline Type of operation & \multicolumn{1}{|c|}{ Brazil } & \multicolumn{1}{c|}{ Russia } & \multicolumn{1}{c|}{ India } & \multicolumn{1}{c|}{ China $^{\text {a }}$} & \multicolumn{1}{c|}{$\begin{array}{c}\text { Africa } \\
\text { TOTAL }\end{array}$} & \multicolumn{1}{c|}{ TOT } \\
\hline Acquisitions & $38(27)$ & $9.9(7)$ & $5.6(4)$ & $21.1(15)$ & $25.4(18)$ & $100(71)$ \\
\hline JV & $5.2(4)$ & $18.2(14)$ & $20.8(16)$ & $51.9(40)$ & $3.9(3)$ & $100(77)$ \\
\hline Cooperation agreement & $20(3)$ & $26.7(4)$ & $6.7(1)$ & $40(6)$ & $6.7(1)$ & $100(15)$ \\
\hline $\begin{array}{l}\text { Greenfield investment of wich: } \\
\text { New industrial plant }\end{array}$ & $10(1)$ & $50(5)$ & $0(0)$ & $30(3)$ & $10(1)$ & $100(10)$ \\
\hline New affiliate & $0(0)$ & $26.3(0)$ & $5.3(1)$ & $68.4(13)$ & $0(0)$ & $100(19)$ \\
\hline
\end{tabular}

a. Includes 14 operations in Hong Kong.

Note: Author's calculations based on AGRODATA

However, substantial differences between the types of operations performed in different target countries can be observed (Table 2). Two groups of countries and two distinct types of strategies can be found: In Brazil and South Africa, major food and beverage MNEs preferred to enter the market via acquisitions, while the importance of JVs was quite low. In contrast, in China, India and Russia, these companies preferred to enter via JVs, while acquisitions were far less important than in Brazil and South Africa.

Brazil and South Africa accounted, respectively, for $38.0 \%$ and $25.4 \%$ of the total number of acquisitions of major MNEs in the food and beverage markets of the BRICS. The importance of acquisitions versus other forms of entry by foreign food investors in the South African market (including greenfield investment) is corroborated by a previous study (Gelb \& Black, 2004). These two countries accounted for only $9.1 \%$ of the total number of JVs. In the literature, acquisitions are not viewed as a mode of entry that contribute to improving competition in the local industry, since the number of companies remains the same; nor do they promote collaboration with local actors. The contribution of FDI to employment is small in these cases (Gelb \& Black, 2004) or can even be negative if so called processes of "rationalisation" are undertaken by the new multinational owner. In Brazil, acquisitions have promoted the denationalization of capital in this industry (Farina \& Viegas, 
2005). Furthermore, their actual importance may be underestimated by the data analysed here since they do not include the smaller foreign investors coming from Argentina, Ireland, Mexico and Chile, quite important regarding acquisitions of Brazilian food companies during this period (Farina \& Viegas, 2005). China, India and Russia accounted for $90.9 \%$ of the JVs undertaken by food and beverage MNEs in the BRICS. More than half of them took place in China alone. Cooperation agreements were few and most of them $(66.7 \%$ of this type of operations) were celebrated in China and Russia.

There are several reasons why food and beverage MNEs may prefer to use these forms for operating in this group of countries. In Russia, for instance, foreign food investors are inclined to select a reliable partner who can deal with bureaucracy and anticipate legal changes (Berkum et al., 2007). In China, in spite of apparent liberalisation, the organization and governance of commodity markets can be extremely complex, involving the intervention of many different types of agents in different networks, where power relations are often more important than purely economic considerations (Augustin-Jean, 2010). Foreign food investors probably ignore the subtleties of local power linkages and need a local partner for guidance. In contrast, since the situation may be easier, more familiar for the MNEs in Brazil and South Africa, foreign food investors may be less prone to engage in JVs in those countries. More importantly, policies in China (especially before 1997) and India have induced foreign investors to engage in $\mathrm{JV}$.

As stated, modes of entry and operations implying collaboration with local partners are better able to transmit managerial know-how to the local industry and this may be a weakness of domestic firms in the BRICS (see, for instance,Fleury et al., 2010).

\subsection{Locating R\&D activities in the BRICS}

Firms innovate abroad for many different reasons: to adapt their products to host country tastes, to absorb new knowledge from world centres of excellence, to benefit from low cost, good quality local R\&D, etc. (Blanc \& Sierra, 1999; Cantwell \& lammarino, 2000; OECD, 2005; Reddy, 2005). 
A review of the literature suggests that MNEs continue to perform much of their innovative activity at home (Dunning \& Lundan, 2009). However, various authors are currently calling attention to a new phenomenon, namely the alleged preference of Triad-based companies for offshoring R\&D to emerging economies (Bardhan \& Jaffee, 2004; Edler, 2008).

As stated, major food and beverage MNEs are key players in the worldwide technological development of the food chain, including technology employed in agriculture, food and beverage processing and auxiliary industries (e.g. food packaging) (Christensen et al., 1996; von Tunzelmann, 1998). Apparently, these companies are especially likely to undertake their R\&D activities abroad (O Alfranca et al., 2005; P. Patel, 1995), probably because it is essential for them to adapt their products to different national tastes and food safety regulations.

Firms rarely provide information on their R\&D expenditures broken down by geographic location. Therefore, empirical studies on R\&D corporate internationalisation often measure the innovative performance of firms using patent data ${ }^{23}$. Research work discussed here is based on patent analyses.

Information on the inventor's country of residence contained in patent documents enables researchers to analyse changes in the geography of corporate R\&D. According to the OECD (2005), this information gives an indication of where the technology has been produced. A study which analysed 8,626 European Patent Office (EPO) ${ }^{24}$ applications filed by 59 major European food and beverage MNEs and the 3,650 United States Patent Office (USPTO) patents ${ }^{25}$ they applied for, found that the generation of inventions is becoming more geographically decentralised in European food and beverages MNEs (Martínez \& Rama, 2010). These firms are food and beverages processors but

\footnotetext{
${ }^{23} \mathrm{~A}$ patent is a title, granted by a patent office, which gives the holder the right to exclude others from making, using, selling or distributing an invention without his/her consent (e.g. through a licensing agreement) (Martínez \& Rama, 2012). Such a right is legally enforceable in case of infringement, and patents can be granted for inventions on products and processes. They are generally only valid for a maximum of 20 years from the date of filing and are restricted to the geographic area under the jurisdiction of the patent office where protection is sought.

${ }^{24}$ Patents assigned by the European Patent Office (EPO) may protect the intellectual property rights (IPR) of patentees in up to 36 European countries, including both EU countries and nonEU members. For a complete list, see http://www.epo.org/about-us/epo/member-states.html ${ }^{25}$ Patents assigned by the (USPTO) protect the IPR of patentees in the US
} 
they also produce inventions used in agriculture and auxiliary industries, in addition to inventions used in the manufacturing of foodstuffs.

The study lists the locations where European food and beverage MNEs produce at least one invention for which they seek protection though EPO patents in descending order, i.e. first the countries where the companies achieve the most patents. The variable which indicates the number of patents by country is split into quarters. In other words, the study analyses the distribution of R\&D locations by quartiles ${ }^{26}$. The $4^{\text {th }}$ group of countries accounts for the upper $25 \%$ of the data above the upper quartile and includes the preferred geographical locations for R\&D. In 1978-1989, the $4^{\text {th }}$ group included exclusively industrialised countries. Three countries among those studied in this chapter were reported in the $2^{\text {nd }}$ quartile: India, Brazil and South Africa. In this first period, China and Russia were not among the locations where major European food and beverages MNEs achieved their patents. India was the most important location among the BRICS.

In 1990-2005, the $4^{\text {th }}$ group, i.e. the preferred locations for R\&D, included 12 countries: India and 11 industrialised countries. India, now of similar importance to Sweden as a location for companies' R\&D (1.2\% of the inventions for which they seek patent protection in Europe), is currently the most important destination for R\&D outside the Triad. Brazil, ranking in a position comparable to that of Spain or Australia, two competitive producers of food, was in the $3^{\text {rd }}$ quartile. South Africa also was in the $3^{\text {rd }}$ quartile but ranked behind Brazil and other developing countries. In 1990-2005, European food and beverage MNEs started producing some patented inventions in China and Russia. China was in the $2^{\text {nd }}$ quartile. Russia, in the $1^{\text {st }}$ quartile, ranked among the world's least important locations for R\&D in the network of European food and beverage MNEs. Comparison between both periods reveals some important changes in the geography of corporate R\&D between the periods 1978-1989 and 1990-2005. Top European food and beverage MNEs performed $R \& D$ in more countries in the latter period. Also, the share of their patented inventions generated in emerging countries rose, notably those in India and, to

\footnotetext{
${ }^{26}$ In statistics, a quartile is anyone of the three values which divide data into four equal parts.
} 
a lesser extent, Brazil. The analysis of USPTO patents confirms, according to the study, the above mentioned findings.

The above analysis provides an approach to the quantitative side of the patenting activities of the companies but does not reflect the scientific or commercial value of the inventions, and hence their ability to improve technological capabilities in the host country. I turn now to this question.

As noted by Blomström and Kokko (1996), not much is known about what type of R\&D is done in affiliates in developing countries; traditionally, much has been adaptation of products and processes. Also, it has been claimed that MNEs perform their most strategic and valuable innovative activities in the home-country. In addition, functions of control and management of R\&D across the multinational network also tend to be performed at the headquarters of companies. In the following paragraphs, I discuss to what extent food and beverage MNEs decentralise these valuable research-related activities towards BRICS.

According to the literature, inclusion in a triadic patent family suggests that the invention is highly valuable. These are patents related to one another by one or more similar filings and they are filed in the three major worldwide patent offices, namely the EPO, USPTO and the Japan Patent Office (JPO). Figure 9 maps triadic patent families granted to major European food and beverage MNEs by country of residence of the inventor. Again, this information contained in the patent approximates the location of the invention. Major European food and beverage MNEs generate most of these valuable inventions in Western Europe and the US, though developing countries also play some role. India and China seem to be more important locations in this respect than Brazil, Russia or South Africa.

The location of specialised R\&D affiliates also provides some information on the role assigned by the MNE to different host-countries regarding the innovative activities of the multinational network. These affiliates may perform patentable and non-patentable R\&D (e.g. basic research), but their most important role is the control and management of innovation within the multinational network (F. Filippaios et al., 2009 ). Affiliates specialising in research-related activities are responsible for coordinating and directing 
innovation within the multinational network (Gassmann \& von Zedtwitz, 1998; von Zedtwitz et al., 2004). Such affiliates enjoy independent status and are not merely laboratories attached to MNE production facilities.

Figure 9

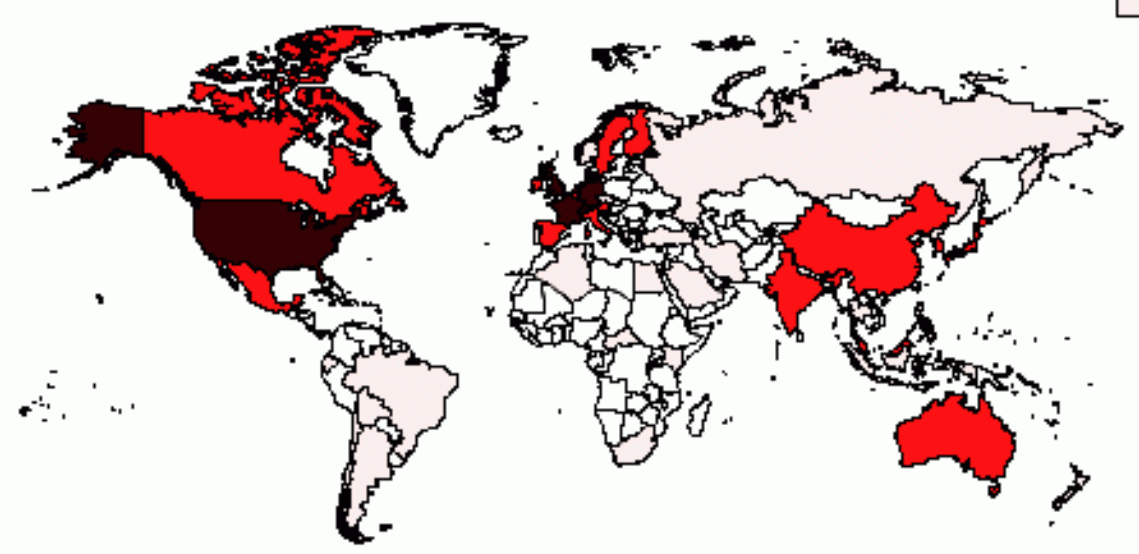

Source: Martínez and Rama (2010)

Major food and beverage MNEs prefer to locate most such affiliates in Europe, Japan and the USA, though they also position some in developing countries (F. Filippaios et al., 2009 ). According to the study, between 1996 and 2000, the share of Brazil, Hong Kong and South Africa in the total number of these affiliates decreased, while the share of China and India, each accounting for $2 \%$ of the total in 2000 , increased ${ }^{27}$. To put the data into relevant perspective, according to the study, Italy and Germany each accounted for 3\% of the total number of these affiliates in 2000. In my view, these developments suggest that China and India are acquiring, as locations, some importance with regard to the superstructures of technology management in major food and

\footnotetext{
${ }^{27}$ In 2000, the sample companies had no specialised R\&D affiliates in Russia.
} 
beverages MNEs. At the same time, Brazil, Hong Kong and South Africa might be losing importance.

There are several possible explanations for the geographic expansion of the R\&D activities of European food and beverage MNEs towards the BRICS. First, corporate R\&D tends to follow, with a time lag, foreign direct investment (FDI) (Blanc and Sierra 1999). In the F\&B industry, because a substantial proportion of innovation consists of small improvements and it is crucial to adapt foodstuffs to national tastes (Galizzi \& Venturini, 2008), companies need to locate their laboratories close to their manufacturing facilities. As shown in section 4, the BRICS seem to be important locations for the production affiliates of European food and beverage MNEs. This circumstance strongly encourages companies to select these countries as "loci" for their innovative activities. The internationalisation of $R \& D$ may be following the internationalisation of production. Secondly, the trend towards the BRICS may be aimed at reducing costs by recruiting highly qualified scientists from nations where salaries are lower than in the Triad (Reddy, 2000). Finally, policies favouring technology transfer have played a role in countries such as India and China.

The empirical evidence does not support the idea that European food MNEs are displaying a shift of corporate R\&D toward emerging countries, as may be the case for companies, for instance, in the electronics industries (Bruche, 2009; Reddy, 2000). Nevertheless, some of the BRICS are now among the preferred locations of these firms to perform R\&D.

At the same time, some differences may be observed within this group of countries. The evidence seems to support the contention that China and India are even beginning to attract investment in advanced areas of R\&D (Asakawa \& Som, 2008, p.382). The "advanced areas of R\&D" are accounted for here, as shown by the discussion, by inventions protected by triadic patents and the infrastructure of control and management of R\&D within the MNE. These countries may attract R\&D not only in high tech industries, as has often been claimed, but they are also attracting the most valuable R\&D activities within an industry considered as low tech but which may have a carrier effect.

As noted in Chapter (Naude et al), host countries may benefit from R\&D contributed by multinationals only if their national systems of innovation display enough absorptive capacity. No empirical data are available concerning the 
specific absorptive capacity of the agro-food system of innovation in the BRICS. However, complementary evidence suggests that the technology gap between F\&B affiliates and the domestic food and auxiliary industries may be relatively small in some middle income countries, as compared to the gap in high tech industries (Alcorta \& Peres, 1998; Christensen et al., 1996). These circumstances may facilitate the absorption of new knowledge transmitted by foreign investors to the domestic F\&B industry and auxiliary industries. Nevertheless, this is still an open question.

\section{Conclusions}

This chapter studied whether FDI may contribute to the development of the food and beverages industries of the BRICS, especially via the transmission of managerial capabilities and spillovers of knowledge.

FDI is contributing to structural change in the food and beverages industries of the BRICS, given its strong presence in high value-added sub sectors. To evaluate the possible benefits accruing to the host-economies, effects on local agriculture and the balance of payment should be carefully analysed.

The effects of increases of income resulting from development are often felt mainly in increased food demand. Expansion of these firms in markets of high value added foodstuffs and beverages has certainly contributed to diversity and probably to increased quality of foodstuffs in the BRICS, given the need of companies to protect the prestige of their brands all over the world. However, low-income consumers, who account for the majority of the population in those countries, often cannot afford the products marketed by MNEs, or at least not many of them. Research work on these countries suggests that the informal sector, certain domestic companies and smaller foreign investors have sometimes displayed greater ability than major MNEs to cater to low income consumers.

Large internal markets, dynamic rates of growth and quick processes of urbanisation may have attracted these investments to BRICS. Some degree of 
protectionism has also been a powerful attractor, as predicted by theory (Gopinath et al., 1999). In addition to attractors common to all sector (e.g. less bureaucracy), specific attractors of FDI to this industry seem to be agricultural education and training, good communications in rural areas, clear land property rules and efficient retailing systems.

Though comparisons are risky owing to the use of different types of empirical evidence, note that while the bulk of global FDI has gone to China, India and Russia (Naudé et al Chapter), the bulk of FDI in foods and beverages seems to have gone to China and Brazil. However, important changes may be talking place.

Firstly, data on outward flows suggest that US food and beverages investments may be shifting from Brazil to China. Data on the restructuring operations of major companies in this industry, independently of their origin, seem to corroborate this interpretation. Almost all their divestitures (e.g. closure of industrial plant, selling of affiliate or selling off stock) have taken place in Brazil (and South Africa). In my view, this is no coincidence. The two threads of evidence seem to confirm the presence of a geographic shift. One reason may be increasing competition and the emergence of strong domestic firms in the F\&B industry of Brazil, and increasing familiarity of Western investors with the Chinese market.

Secondly, in China, US food and beverages investments may be substituting in part Japanese food and beverages investments, which are currently shrinking. MNEs based in different home countries could make different contributions to the host country (Buckley et al., 2007). The above mentioned substitution may not be neutral for the host-country. The literature suggests that Japanese and overseas Chinese food and beverages investors are more likely to provide access to the international market than Western food and beverages investors. Also, compared to their US counterpart, large Japanese food and beverages investors (not necessarily smaller Japanese firms) are usually more innovative and more willing to engage in international $R \& D$; the organisation of their R\&D activities is more conducive to the integration of different sciences and techniques, notably biotechnology ( $F$. 
Filippaios et al., 2009 ; von Tunzelmann, 1998). However, the question deserves more research than attempted here.

The analysis of their restructuring operations shows that large food and beverages MNEs have used M\&A rather than Greenfield investment to penetrate the markets of the BRICS. This suggests that their contribution to capital creation in these F\&B industries is limited. Moreover, this contribution has been largely concentrated in the F\&B industries of China and Russia, which accounted respectively for $80 \%$ of new industrial plant creation and for nearly $95 \%$ of new affiliate creation in this group of countries. By contrast, the contribution of major foreign investors to capital formation in the F\&B industries of Brazil, India and South Africa has been quite small. This interpretation is coherent with the analysis presented in Chapter (Naudé et al ) since these countries also displayed the lowest levels of global greenfield FDI in this group. Again, comparisons should be taken with some degree of caution owing to the use of different sources of information.

The chapter has also inquired whether food and beverage MNEs are embedded in the local economies and the question has been tackled from three different angles: acquaintance of the MNE with the milieu, business linkages with local partners and performance of R\&D in the host-country.

Historically, food and beverage MNEs appear to have been more acquainted on a continuous base with the Brazilian milieu than with any other in the BRICS. As reported by empirical studies, this familiarity seems to have facilitated a variety of local linkages, such as the local outsourcing of certain agricultural products and purchases of local capital goods (Franco et al 2011, (Quadros et al., 2001). However, it does not seem to have particularly encouraged business collaborations with Brazilian partners. On the contrary, in Brazil and South Africa, major food and beverage MNEs have preferred to acquire domestic firms rather than establishing JVs with local partners. It has often been suggested that a long experience in the host-country may help companies to build local linkages, but the above mentioned results do not support this idea. In contrast, JVs have been very important in China, India and Russia. Possible reasons are local policies which required the establishment of JVs and the need to recruit reliable local partners to deal with bureaucracy or, in 
China, with the complex governance of internal commodity markets. There can be no doubt that acquisitions have little positive effects on the transmission of managerial skills to the local industry. Yet, managerial skills, according to certain authors, may be problematic for Brazilian firms (Fleury et al); hence, the interest of a transmission of know-how. To conclude, from a business point of view food and beverage MNEs seem to be more embedded in the local economies of China, India and Russia, in spite of longer familiarity and experience with the South African, and especially the Brazilian economies. The potential for the transmission of managerial skills to the local industry is likely to be less significant in the latter mentioned countries. As stated, almost all Greenfield investments of food and beverage MNEs have taken place in China and Russia. These operations do not imply linkages with local partners and, hence, the potential of spillovers of knowledge. However, the fact is that they may contribute to increasing the level of competition in the industry and to creating new jobs.

Let us turn now to the innovative activities of major European food and beverage MNEs in the BRICS. These companies still retain most of these activities in Europe and the US. However, the BRICS are acquiring increasing importance as "loci" for their innovative activities. For these companies, India has become the most important location outside the Triad. In the BRICS, MNEs generate a greater number of patented inventions in India and Brazil. Within this group of countries, South Africa and, especially, Russia are the least popular locations for such activities. In consequence, transfers of technology to the local industry seem more likely in Brazil and, especially, in India.

This leaves the question as to where in this group of countries these MNEs perform quality R\&D. As noted by Cantwell and Dunning (1991), many MNEs based in Europe and the US have emphasized adaptation rather than the creation of new technology. Some studies have proposed indicators of quality $R \& D$ in the food and beverages industry. Firstly, triadic patents are considered to protect especially valuable inventions. European food and beverages MNEs tend to generate them in India and China, while the role of the rest of the BRICS is less important in this respect. Another step in answering the question about quality $R \& D$ was to analyse the geographic distribution of the specialized R\&D 
affiliates of these MNEs. These affiliates are not mere laboratories attached to factories, but rather instruments for coordinating and managing R\&D within the multinational network. They may perform both patentable innovation and basic research. They appear to be indicators of "loci" for quality research. Though other BRICS countries play some role in this respect, major food and beverage MNEs tend to locate their specialized R\&D affiliates in India and China.

Buckley et al (2007) gave strong reasons for concluding that organization through the form of JVs of large foreign MNEs in China's telecom and automobile sectors limited their capacity to transmit new knowledge. In the food and beverage industry, by contrast, this form of organization does not seem to have hampered the location of quality R\&D. In fact, India and China, two of the countries where the weight of JVs in the organization of foreign food and beverages investors is more substantial, are the same countries chosen by these companies to locate quality R\&D. In contrast, they locate a great number of their innovative activities in Brazil, but apparently few of the most important ones. However, as previously stated, acquisitions seem to have played an important role in the expansion of food and beverage MNEs in Brazil.

These results suggest that the policies of India and China for technology transfer from foreign investors may be bearing fruits in the F\&B industry, as the first step towards technology transfer is the location of quality R\&D in the hostcountry.

A limitation of the above analysis is that it focuses on major F\&B multinationals. The effect of other F\&B foreign investors is still little understood. The analysis of Buckley et al (2007) suggests that, in China, investments from Hong Kong, Macau and Taiwan may be providing a low technological contribution in low tech industries such as food.

Acknowledgements. The author is grateful to Selma Tozanli for providing access to the AGRODATA database; to Conchi Murillo and María Angeles Toribio for their help with the data; and to the editors and Dr Ludovico Alcorta for useful comments and suggestions on an early draft. 


\section{References}

Alcorta, L., \& Peres, W. (1998). Innovation systems and technological specialization in Latin America and the Caribbean. Research Policy, 26, 857-881.

Alfranca, O., Rama, R., \& von Tunzelmann, N. (2002). A patent analysis of global food and beverage firms: the persistence of innovation. Agribusiness. An International Journal, 18(3), 349-368.

Alfranca, O., Rama, R., \& von Tunzelmann, N. (2004). Combining different brands of in-house knowledge: technological capabilities in food, biotechnology, chemicals and drugs in agri-food multinationals. Science and Public Policy, 31, 227-244.

Alfranca, O., Rama, R., \& von Tunzelmann, N. (2005). Innovation in food and beverage multinationals. In R. Rama (Ed.), Multinational agribusinesses (pp. 13-50). New York and London: Haworth Press Inc.

Amatucci, M., \& Avrichir, I. (2008). Teorías de negócios internacionáis e a entrada de multinacionais no Brasil de 1850 a 2007. Revista Brasileira de Gestao de Negocios, 10(028), 234-248.

Andersen, E. S., \& Lundvall, B.-A. (1988). Small national systems of innovation facing technological revolutions: an analytical framework. In F. C. \& B.-A. Lundvall (Eds.), Small Countries Facing the Technological Revolution. London and New York: Pinter Publishers.

Arroyo, G., Rama, R., \& Rello, F. (1985). Agricultura y alimentos en América Latina. El poder de las transnacionales. Madrid: UNAM-Instituto de Cooperación Iberoamericana.

Asakawa, K., \& Som, A. (2008). Internationalization of R\&D in China and India: Conventional wisdom versus reality. Asia Pacific J.of Management, 25, 375$\underline{394 .}$

Athukorala, P., \& Sen, K. (1998). Processed food exports from developing countries: patterns and determinants. Food Policy, 23(1), 41-54.

Augustin-Jean, L. (2006). Les investissements directs étrangers agro-alimentaires japonais en Chine et la recomposition des territories: du global au local. Géographie, Économie, Société, 8, 125-148.

Augustin-Jean, L. (2010). The "social construction of the market" in a transitional economy. Economic Sociology, 11(3), 33-43.

Ayadi, N., Rastoin, J.-L., \& Tozanli, S. (2006). Les Operations de Restructuration des Firmes Agroalimentaires Multinationales entre 1987 et 2003. Montpellier (France): Unité Mixte de Recherche MOISA.

Bardhan, A. D., \& Jaffee, D. (2004). On intra-firm and multinationals: foreign outsourcing and offshoring in manufacturing (pp. 1-23, http://www.brookings.edu/pge/offshoring_Bardhan.pdf): Haas School of Business.

Barkley, A. P. (2005). Multinational food corporations and trade: the impact of Foreign Direct Investment on trade in the U.S. food industry. In R. Rama (Ed.), Multinational Agribusinesses (pp. 165-190). N.Y. and London: Haworth Press $\underline{\text { Inc. }}$

Baskaran, A., \& Muchie, M. (2008). Foreign Direct Investment and internationalisation of R\&D: The case of BRICS economies. Development, Innovation and International Political Economy Research (DIIPER), Working Paper no. 7.

Belik, W. (1994). The Food Industry in Brazil: Towards a Restructuring? London: Institute of Latin American Studies Research Papers. 
Belik, W., \& Rocha dos Santos, R. (2002). Regional market strategies of supermarkets and food processors in extended MERCOSUR. Development Policy Review, 20(4), 515-528.

Berkum, S. v., Roza, P., \& Belt, J. (2007). Long-term perspectives for the Russian agrifood sector and market opportunities for the Dutch agribusiness. LEI Agricultural Economics Research Institute, The Hague, Report 5.07.03.

Blanc, H., \& Sierra, C. (1999). The internationalisation of R\&D by multinationals: a trade-off between external and internal proximity. Cambridge Journal of Economics, 23, 187-206.

Blomström, M., \& Kokko, A. (1996). The Impact of Foreign Investment on Host Countries: A Review of the Empirical Evidence (Working paper). Washington D.C.: World Bank.

Bolling, C., Neff, S., \& Handy, C. (1998). U.S. foreign investment in the Western Hemisphere processed food industry. Agricultural Economics, 760(www.ers.usda.gov), 1-7.

Bolling, C., Somwaru, A., \& Crook, F. (not dated). U.S. Foreign Direct Investment in China's processed food industry Washington DC: ERS-USDA.

Bruche, G. (2009). A new geography of innovation. China and India raising. Columbia FDI Perspectives, 4(Abril).

Buckley, P. J., Clegg, J., \& Wang, C. (2007). Is the relationship between inward FDI and spillover effects linear? An empirical examination of the case of China. Journal of International Business Studies, 38, 447-459.

Caballero, J., O'Connor, E., \& Amado, B. (2011). Latin America's agricultural exports to China:Recent trends, Will the BRICs decade continue? Prospects for trade and growth. Halle, Germany.

Cantwell, J., \& Dunning, J. (1991). MNEs, technology and the competitiveness of European industries. Aussenwirtschaft, 46(1), 45-65.

Cantwell, J., \& Iammarino, S. (2000). Multinational corporations and the location of technological innovation in the UK regions. Regional Studies, 34(4), 317-332.

Cantwell, J., \& Janne, O. (2000). Globalization of innovatory capacity: the structure of competence accumulation in European home and host countries. In F. Chesnais, G. Ietto-Gillies \& R. Simonetti (Eds.), European integration and global corporate strategies (pp. 121-177). London-NY: Routledge.

Caswell, J. A. (1987). Dominant Forms of Corporate Control in the US Agribusiness Sector. American Journal of Agricultural Economics, 69(1), 11-21.

Caves, R. E. (1996). Multinational enterprise and economic analysis (2nd ed.): Cambridge University Press.

CEPAL. (1983). Empresas transnacionales en la industria de alimentos. El caso argentino: cereales y carne. Santiago (Chile): UN-Economic Commission for Latin America.

Copeland, T. E., \& Weston, J. F. (1992). Financial Theory and Corporate policy. Reading, Massachusetts: Addison-Wesley Publishing Company.

CTC. (1981). Transnational corporations in food and beverages processing. New York: UN Centre on Transnational Corporations ST/CTC/19.

Cuervo-Cazurra, A., Maloney, M. M., \& Manrakhan, S. (2007). Cause of the difficulties in internationalization. Journal of International Business Studies, 38, 709-725.

Chobanova, Y. (2009). Strategies of multinationals in Central and Eastern Europe: Innovation Systems and Embeddedness: Palgrave McMillan. 
Christensen, J. L., Rama, R., \& von Tunzelmann, N. (1996). Study on Innovation in the European Food Products and Beverages Industry (No. EIMS SPRINT). EIMS/SPRINT Brussels: The European Commission.

da Silva, H. J. T. (2011). Levantamento e estruturaçao de dados sobre capital internacional no agronegócio e na economia nacional. Picicaba S.P. Brazil: Universidade de Sao Paulo.

Dasgupta, N. (2011). FDI retailing and inflation: the case of India. Columbia FDI Perspectives, 52(December 5).

Dunning, J. H., \& Lundan, S. M. (2009). The internationalization of corporate R\&D: A review of the evidence and some policy implications for home countries. Review of Policy Research, 26(1-2), 13-34.

ECLAC (Ed.). (2005). Trans-latins in the food and beverages industry. Santiago de Chile: ECLAC (UN).

Edler, J. (2008). Creative internationalization: widening the perspectives on analysis and policy regarding international R\&D activities. Journal of Technology Transfer, 33, 337-352.

EUROSTAT, Financial Account, Direct Investment Abroad of EU-27

FAO. http://faostat3.fao.org.

Farina, E., \& Viegas, A. (2005). Multinational Firms in the Brazilian Food Industry. In R. Rama (Ed.), Multinational agribusinesses. New York and London: Haworth Press.

Feldman, M. P., \& Audretsch, D. B. (1996). Location, Location, Location: The Geography of Innovation and Knowledge Spillovers. Berlin: Wissenschaftszentrum.

Filippaios, F., Pearce, R., Papanastassiou, M., \& Rama, R. (2009). New forms of organisation and R\&D internationalisation among the world's 100 largest food and beverages multinationals. Research Policy, 38, 1032-1043.

Filippaios, F., \& Rama, R. (2011). Cultural distance and internationalization. The world's largest food and drink multinationals

Agribusiness. An International Journal, 27.

Fleury, A., Leme-Fleury, M. T., \& Glufke-Reis, G. (2010). El camino se hace al andar: La trayectoria de las multinacionales brasileñas. Universia Business Review, primer cuatrimestre.

Flores, R. G., \& Aguilera, R. V. (2007). Globalization and location choices: an analysis of US multinational firms in 1980 and 2000. Journal of International Business Studies, 38, 1187-1210.

Franco, E., Ray, S., \& Ray, P. K. (2011). Patterns of innovation practices of multinational-affiliates in emerging economies: evidences from Brazil and India. World Development, 39(7), 1249-1260.

Galizzi, G., \& Venturini, L. (2008). Nature and determinants of product innovation in a competitive environment of changing vertical relationships. In R. Rama (Ed.), Handbook of innovation in the food and drink industry (pp. 51-80). New York and London: Taylor \& Francis Group.

Gassler, H., \& Nones, B. (2008). Internationalisation of R\&D and embeddedness: the case of Austria. Journal of Technology Transfer, 33, 407-421.

Gassmann, O., \& von Zedtwitz, M. (1998). Organization of industrial R\&D on a global scale. R\&D Management, 28(3), 147-161.

Gelb, S., \& Black, A. (2004). Foreign Direct Investment in South Africa. In S. Estrin \& K. E. Meyer (Eds.), Investment strategies in emerging markets (pp. 177-212): Edward Elgar Publishing. 
Geroski, P., \& Vlassopoulos, T. (1991). The Rise and Fall of a Market Leader: Frozen Foods in the UK. Strategic Management Journal, 12, 467-478.

Goerzen, A., \& Beamish, P. W. (2003). Geographic scope and multinational enterprise performance. Strategic Management Journal, 24, 1289-1306.

Goodman, D. (2003). The quality 'turn' and alternative food practices: reflections and agenda. Journal of Rural Studies, 19, 1-7.

Gopinath, M., Pick, D., \& Vasavada, U. (1999). The economics of foreign direct investment and trade with an application to the U.S. food processing industry. American Journal of Agricultural Economics, 81, 442-452.

Grebe, H., \& Kñakal, J. (1987). Las empresas transnacionales en la agroindustria de alimentos en América Latina. Santiago de Chile: CEPAL (UN Economic Commission for Latin America).

Heyder, M., \& Theuvsen, L. (2011). Strategies and challenges of internationalisation in BRIC-countries: Empirical results from the German agribusiness. The Open Access Publication Server of the ZBW-Leibnitz Information Centre for Economics, IAMO Forum 2011, 22.

Hunya, G., \& Stöllinger, R. (2009). Foreign Direct Investment flows between the EU and the BRICs. The Vienna Institute for International Economic Studies Vienna, Research Reports 358.

Ietto-Gillies, G. (2005). Transnational corporations and international production. Concepts, theories and effects. Cheltenham, UK and Northampton US Edward Elgar.

Japan Ministry of Finance, Balance of Payment (www.mof.go.jp/english).

Jones, G. (2005). Managing governments: Unilever in India and Turkey, 1950-1980 (pp. 1-47, Working paper 06-061, http://www.hbs.edu/research/pdf/006061.pdf): Faculty \& Research.

Makki, S. S., Somwaru, A., \& Bolling, C. (2004). Determinants of foreign direct investment in the food-processing industry: a comparative analysis of developed and developing economies. Washington DC: The Market and Trade Economics Division of ERS.

Martínez, C., \& Rama, R. (2010). The geography of corporate R\&D in the international food and beverage industry: location patterns of European MNEs, 2010 Industry Studies Association Conference, Globalization of Value Creation and Capture. Chicago.

Martínez, C., \& Rama, R. (2012). Home or next door? Patenting by European food and beverage multinationals. Technology Analysis \& Strategic Management, 24(7), 647-661.

Meyer, K. E., Mudambi, R., \& Narula, R. (2011). Multinational enterprises and local context: the opportunities and challenges of multiple embeddedness. Journal of Management Studies, 48(2).

Muller, A., \& Van Tulder, R. (2005). Exploring Patterns of Upstream Internationalization: The Role of Home-region 'Stickiness'. ERS-2005-084ORG

ERIM Report Series Research in Management.

Nazareth Satyanand, P. (2011). India's Agriculture and Food Multinationals: A First Look. Transnational Corporations Review 3(2), 31-49.

OECD. (2004). Handbook on economic globalisation indicators. Paris: OECD.

OECD. (2005). Background report. Internationalisation of $R \& D$ : Trends, issues and implications for S\&T policies. A review of the literature. Brussels: OECD Forum on the Internationalisation of R\&D. 
Osegowitsch, T., \& Sammartino, A. (2008). Reassesing (home-)regionalisation. Journal of International Business Studies, 39, 184-196.

Palpacuer, F., \& Tozanli, S. (2008). Changing governance patterns in European food chains: the rise of a new divide between global players and regional producers. Transnational Corporations, 17(1), 69-100.

Patel, P. (1995). Localised production of technology for global markets. Cambridge Journal of Economics, 19, 141-153.

Patel, P., \& Pavitt, K. (1991). Large firms in the production of the world's technology: an important case of 'non-globalisation. Journal of International Business Studies, 22, 1-21.

Pick, D., \& Worth, T. (2005). Foreign direct investment in the U.S. food and kindred products. In R. Rama (Ed.), Multinational Agribusinesses (pp. 149-164). N.Y.London: Haworth Press Inc.

Pozzobon, D. A. (2008). Explorando Soluções Internacionais: o Caso dos Frigoríficos Brasileiros, XXXII Encontro en ANPAD. Rio de Janeiro.

Quadros, R., Furtado, A., Bernardes, R., \& Franco, E. (2001). Technological innovation in Brazilian industry: An assessment based on the Sao Paulo innovation survey. Technological Forecasting and Social Change, 67, 203-219.

Rama, R. (1985). Some effects of the internationalization of agriculture on the Mexican agricultural crisis

In S. E. Sanderson (Ed.), The Americas in the new international division of labor

(pp. 69-94). N.Y. and London: Holmes \& Meier.

Rama, R. (1992). Investing in Food. Paris: OECD Development Centre Studies.

Rama, R., \& Wilkinson, J. (2008). Foreign direct investment and agri-food value-chains in developing countries: a review of the main issues Commodity Markets Review, 2007-2008, 51-66.

Rama, R., \& Wilkinson, J. (2012). Asian agribusiness investment in Latin America with case studies from Brazil. Santiago de Chile: CEPAL.

Ramamurti, R. (2008). What have we learned about EMNEs. In R. Ramamurti \& J. V. Singh (Eds.), Emerging multinationals from emerging markets. Cambridge, UK: Cambridge University Press.

Reardon, T., Timmer, P., \& Berdegué, J. (2004). The rapid rise of supermarkets in developing countries: induced organizational, institutional, and technological changes in agrifood systems. eJade (electronic Journal of Agricultural and Development Economics) www.fao.org/es/esa/eJADE, 1(2), 15-20

Reddy, P. (2000). Globalization of R\&D. Implications for innovation systems in host countries. London \& New York: Routledge.

Reddy, P. (2005). R\&D-related FDI in developing countries: implications for hostcountries. Paper presented at the Proceedings of the Expert Meeting Globalization of R\&D and Developing Countries, Geneva.

Rugman, A. (2003). Regional strategy and the demise of globalization. International Journal of Management, 9(4), 409-417.

Schmidhuber, J., \& Traill, W. B. (2006). Features of the Atlantic diet and its healthiness: theory and evidence from social science, EJEAFCHE (Electronic Journal of Environmental, Agriculture and Food Chemistry) (Vol. 5, pp. 1-21): EJEAFCHE.

Senauer, B. (1990). Major consumer trends affecting the US food system. Journal of Agricultural Economics, 41(3), 422-430.

Shono, C., Suzuki, N., \& Kaiser, H. M. (2000). Will China's diet follow Western diets? Agribusiness. An International Journal, 16(3), 271-279. 
Stopford, J. M., \& Dunning, J. H. (1983). Multinationals. Company performance and global trends. London: McMillan Publishers.

Survey of Current Business 2012 Balance of Payments and Direct Investment

Position Data.

Tozanli, S. (2005). The rise of global enterprises in the world's food chain. In R. Rama (Ed.), Multinational Agribusinesses (pp. 1-72). N.Y.: Haworth Press Inc.

UNCTAD. (2009). World Investment Report 2009. Transnational corporations, agricultural production and development. Geneva: United Nations.

UNCTAD (Ed.). (2001). World Investment Report 2001. Promoting Linkages. New York and Geneva: United Nations Conference on Trade and Development.

UNCTAD. http://www.unctad.org/

von Tunzelmann, G. N. (1998). Localized technological search and multi-technology companies. Economics of Innovation and New Technology, 6, 231-255.

von Zedtwitz, M., Gassmann, O., \& Boutellier, R. (2004). Organizing global R\&D, challenges and dilemmas. Journal of International Management, 10, 21-49.

Wei, A., \& Cacho, J. (2001). Competition among foreign and Chinese agro-food enterprises in the process of globalization. International Food and Agribusiness Management Review, 2(3/4), 437-451.

Wilkinson, J. (2002). The final foods industry and the changing of the global agro-food system. Sociologia Ruralis, 42(4), 329-346.

Wilkinson, J. (2006). O sector de lácteos no Brasil no contexto de globalizaçao - inputs para pesquisa (pp. 1-26): CPDA/UFRRJ. 